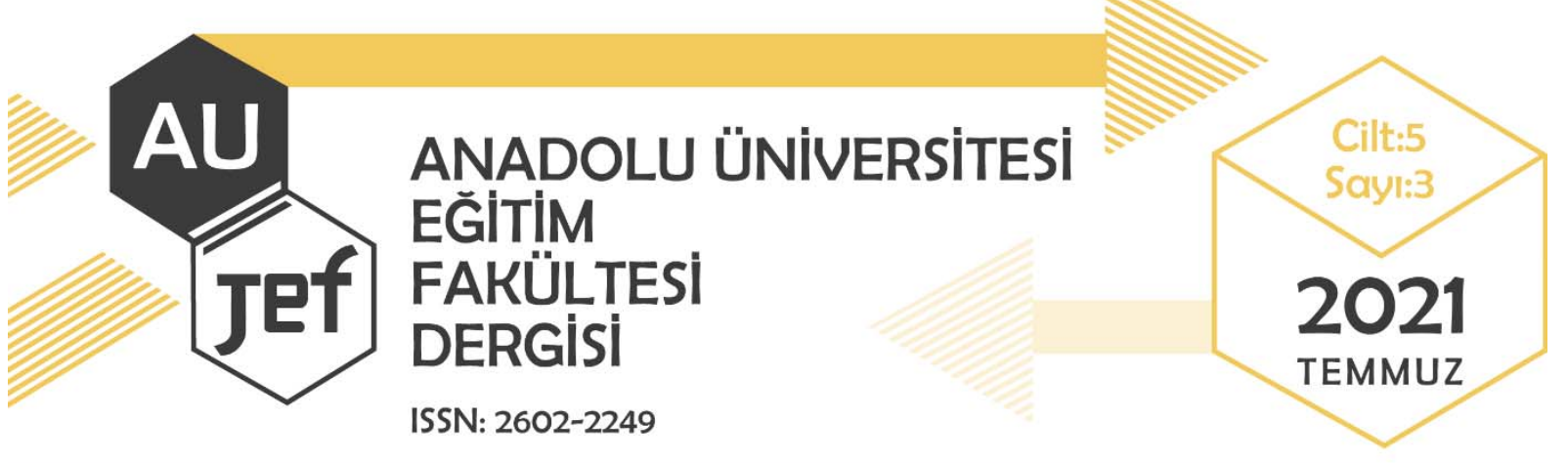

\title{
Yükseköğretim Öğrencilerinin Koronavirüs (Covid-19) Pandemi Sürecinde Uzaktan Eğitime Yönelik Algıları
}

\section{Higher Education Students' Perceptions of Distance Education during the Coronavirus (Covid-19) Pandemic}

\author{
Dilara Arzugül AKSOY ${ }^{1}$, Aras BOZKURT ${ }^{2}$, Engin KURŞUN ${ }^{3}$
}

Makale Türü4: Araştırma Makalesi

Başvuru Tarihi: 20.03.2021

Kabul Tarihi: 22.06.2021

Atıf İçin: Aksoy, D. A., Bozkurt, A. ve Kurşun, E. (2021). Yükseköğretim öğrencilerinin Koronavirüs (Covid-19) pandemi sürecinde uzaktan eğitime yönelik algıları. Anadolu Üniversitesi Eğitim Fakültesi Dergisi (AUJEF), 5(3), $285-308$

ÖZ: Koronavirüs (Covid-19) pandemisiyle beraber yaşanan kriz ortamında eğitimin devamlılığını sağlamak ve eğitimi sürdürülebilir kılmak adına [acil] uzaktan eğitim uygulamaya konulmuştur. Bu bağlamda araştırmanın amacı, yükseköğretim öğrencilerinin Covid-19 pandemisi sürecindeki uzaktan eğitim algılarını nitel olgubilim (fenomenoloji) yöntemi çerçevesinde metafor analizi ile incelemektir. Araştırmanın katılımcıları; yüksek lisans, lisans ve ön lisans seviyelerinde 82 üniversite öğrencisinden oluşmaktadır. Veri toplama sürecinde, araştırmacılar tarafından çevrimiçi bir form hazırlanarak katılımcılardan "Uzaktan eğitim ... gibidir. Çünkü ..." ifadesini tamamlamaları istenmiştir. İçerik analizi ile elde edilen bulgulara göre katılımcılar, 68 olumlu ve 81 olumsuz metafor üretmişlerdir. Olumlu metaforlardan "esneklik", "kullanışl11ık", "öğrenci katıllımı” ve "uygunluk” temaları; olumsuz metaforlardan ise "öğretim süreci", "kullanışlılık", "öğrenci durumu", "ölçme değerlendirme" ve "acil uzaktan öğretim" temaları elde edilmiştir. Öğrenciler, uzaktan eğitim yoluyla öğrenme firsatlarına erişmenin esneklik ve zaman-mekân bağlamında bağımsızlık sağladığını düşünmektedirler. Öte yandan öğrenciler uzaktan eğitimi, etkililiği düşük ve etkileşimi yetersiz olarak değerlendirmektedir. Öğrenciler pandemi bağlamında, uzaktan eğitimi okul öncesi dönemden doktora derecesine kadar eğitimin her kademesini etkileyen acil dönüşüm sürecinin bir parçası olarak algılamaktadırlar.

Anahtar sözcükler: Uzaktan eğitim, Covid-19 pandemisi, çevrimiçi öğrenme, metafor analizi, algı ve tutum

\footnotetext{
ABSTRACT: In order to ensure the continuity of education and to make it sustainable in the crisis environment experienced with the coronavirus (Covid-19) pandemic, [emergency] remote/distance education has been put into practice. The purpose of this study is to examine the higher education students' perceptions of distance education during the Coronavirus (Covid-19) pandemic by employing metaphor analysis through qualitative phenomenology

${ }^{1}$ Öğr. Gör., Bayburt Üniversitesi, dilaraarzugulaksoy@gmail.com, ORCID: 0000-0003-0666-8362

2 Doç. Dr., Anadolu Üniversitesi, arasbozkurt@gmail.com, ORCID: 0000-0002-4520-642X

${ }^{3}$ Doç. Dr., Atatürk Üniversitesi, ekursun@atauni.edu.tr, ORCID: 0000-0002-5649-8595

${ }^{4}$ Etik kurul onayı Bayburt Üniversitesi Etik Kurulu'ndan alınmıştır.
} 
method. The participants of the research consist of 82 students at graduate, undergraduate and associate degree levels. During the data collection process, participants were asked to complete "Distance education is like ... because ..." statement through an online questionnaire form. According to the findings of the study, the participants provided 68 positive and 81 negative metaphors. The themes of "flexibility", "usefulness", "students' participation" and "suitability" were identified by analyzing positive metaphors and "teaching process", "usefulness", "student situation", "assessment and evaluation" and "emergency distance education" themes were identified by analyzing negative metaphors. Students also think that accessing learning opportunities through distance education provides flexibility and independence in the context of time and space. On the other hand, distance education is considered to have low efficiency and provided inadequate interaction. Within the context of the pandemic, students perceive distance education as a part of an urgent transformation process that affects all levels of education from preschool to doctoral degrees.

Keywords: Distance education, Covid-19 pandemic, online learning, metaphor analysis, perception and attitude 


\section{GíRiş}

Covid-19 pandemisi hayatımızın her alanını, özellikle eğitim ve öğretim süreçlerini, önemli derecede etkilemiştir. $\mathrm{Bu}$ bağlamda, eğitimin her kademesindeki öğrenciler Covid-19 pandemisiyle beraber ortaya çıkan yeni normalde, acil uzaktan eğitimin işe koşulması ile eğitim süreçlerini farklı bir şekilde deneyimlemek zorunda kalmışlardır. Eğitimin, her koşulda devam etmesi gereken temel bir ihtiyaç olduğu düşüncesiyle yapılan çalışmalar genelde eğitimi, özelde ise uzaktan eğitimi algılama, deneyimleme ve yorumlama şeklimizi değiştirmiştir.

Uzaktan eğitim, öğretmen ile öğrencinin, zaman ve/veya mekândan bağımsız olarak öğretmeöğrenme faaliyetlerini sürdürdüğü eğitim şeklidir (Keegan, 1988; Moore, 2012; Moore ve Kearsley, 2012). Eğitime normal koşullarda erişemeyen öğrencilere sunduğu olanaklarla firsat eşitliği sağlaması, daha fazla öğrenciye ulaşması, maliyetleri düşürmesi ve her yaş grubunun eğitim ihtiyacını karşılamaya uygun olması sebebiyle uzaktan eğitim, yüz yüze eğitimi destekleyici niteliktedir (Midkiff ve DaSilva, 2000; Valentine, 2002).

Uzaktan eğitim ve yüz yüze eğitimin etkililiğini inceleyen çalışmalar, iki eğitim yaklaşımı arasında istatistiki olarak anlamlı bir fark olmadığını göstermektedir (Russell, 2001). Her ne kadar doğru yapılandırılan uygulamalarda bir fark olmasa da uzaktan eğitimin başarısını etkileyen farklı faktörler de bulunmaktadır. Akranlarını ve öğretmenini yüz yüze göremeyen öğrencinin motivasyon kaybı ve uzaktan eğitime geçiş sürecinde oluşan maliyetler ile kurumsal destek eksiklikleri uzaktan eğitimin başarıya ulaşmasını engelleyen olumsuz faktörlerden bazılarıdır (Galusha, 1998). Bu faktörlerin yanı sıra uzaktan eğitimin yüz yüze eğitime göre daha fazla odaklanma, zaman yönetimi ve bağımsız çalışma becerisi gerektirmesine bağlı olarak öğrencinin ilgili becerilerdeki yetkinlikleri de bu süreci etkilemektedir (Hardy ve Boaz, 1997). Benzer şekilde eğitimcilerin de uzaktan eğitime yönelik algıları ve bu algıdan etkilenerek sundukları eğitim (Lawler, 2003) uzaktan eğitim süreçlerinde öğrenci başarısına etki etmektedir (Valentine, 2002). Genel çerçeveden bakıldığında, uzaktan eğitim sürecindeki en kritik etkenin öğrencilerin eğitim uygulamalarına karşı tutum ve yaklaşımları olduğu ifade edilmektedir (Yıldırım, Yıldırım, Çelik ve Karaman, 2014). Ayrıca teknik ve öğretimsel güçlüklerin yanı sıra (Altınpulluk, 2021) çevrimiçi uzaktan eğitime yönelik yanlış algılar da uzaktan eğitime karşı olumsuz düşüncelerin oluşmasına neden olmaktadır (Karaduman ve Battal, 2021). Dolayısıyla belirtilen algı ve tutumların incelenerek ihtiyaç duyulan düzenlemelerin yapılması, uzaktan eğitimin amacina ulaşması için son derece önemlidir.

İlgili alanyazında; K12 (Sipahi, 2019) ve yükseköğretim düzeyinde öğrencilerin (Ateş ve Altun, 2008; Barış, 2015; Birişçi, 2013; Boz, 2019; Fidan, 2016; Hannay ve Newvine, 2006; Yenilmez, Turğut ve Balbağ, 2017), öğretmenlerin (Ağır, 2007; Horzum, Albayrak ve Ayvaz, 2012) yanı sıra öğretim elemanlarının (Gürer, Tekinarslan ve Yavuzalp, 2016; Yıldız, 2015) uzaktan eğitime yönelik algılarını inceleyen çalışmalar bulunmaktadır. Öğretim elemanlarının algılarını inceleyen Gök (2011), kaynaklara erişim ve temel bakış faktörlerine ilişkin algının orta seviyede, eğitim öğretim planlama faktörüne ilişkin algının ise yüksek seviyede olduğunu ortaya koymuştur. Yükseköğretim öğrencilerinin uzaktan eğitim algılarına yönelik; cinsiyet, kişisel bilgisayara sahip olma ve internet bağlantısına sahip olma değişkenlerinin uzaktan eğitim algısında anlamlı bir fark oluşturmadı̆̆ı; ancak bölüm ve sınıf değişkenlerine göre algının farklılaştığı (Gündüz, 2013); erkek adayların uzaktan eğitim algılarının kadın adaylara göre daha olumlu olduğu, Bilgisayar ve Öğretim Teknolojileri Eğitimi bölümü öğrencilerinin, Fen Bilgisi ve Sınıf Öğretmenliği öğrencilerinden daha yüksek algıya sahip oldukları (Başar ve diğerleri, 2019); kişisel bilgisayara sahip olma ve bilgisayar kullanma değişkenlerine göre algının farklılık gösterdiği (Kırali ve Alc1, 2016) ifade edilmektedir. Belirtilen nicel araştırma paradigmasını benimseyen çalışmalar dışında, uzaktan eğitim algısını metaforlar yoluyla, nitel araştırma paradigmasıyla inceleyen

Anadolu Üniversitesi Ĕ̆itim Fakültesi Dergisi (AUJEF), 5(3), 285-308 
çalışmalar da bulunmaktadır (Bağrıaçık Yılmaz, 2019; Bozkurt, 2020; Fidan, 2017; Taş, Yavuzalp ve Gürer, 2016; Tuncay ve Özçınar, 2009). Çivril ve diğerleri (2018) tarafından üniversite öğrencileriyle gerçekleştirilen bir metafor çalışmasına göre; uzaktan eğitimin esnek bir yapıya sahip olması, dezavantajlı gruplar için erişilebilirliği artırması, akademik ve mesleki eğitime imkân sunması, etkileşimi desteklemesi ve öğrenci motivasyonunu artırması öğrencilerin uzaktan eğitime yönelik algısını olumlu yönde etkilemektedir. Ayrıca, uzaktan eğitimde derslerin eş zamanlı olarak sunulması öğrenci algısını olumlu etkilerken; derslerde teknik problemlerin yaşanması, eş zamanlı derslerin 90 dakikalık bloklar halinde yürütülmesi ve öğretmen adaylarının ders dışında öğretmene soru sorma imkânı bulamaması öğrencilerde olumsuz algıya sebep olmaktadır (Kaleli Yılmaz ve Güven, 2015). İlköğretim öğrencileri ile gerçekleştirilen bir araştırmada ise, öğrencilerin pandemi sürecindeki uzaktan eğitim deneyimleri incelenerek olumlu ve olumsuz metaforlar ortaya çıarılmıştır (Bozkurt, 2020). Metaforlara göre öğrenciler, uzaktan eğitimdeki etkileşimin gerçekliğini düşük düzeyde algılamakta ve sınıf ortamından uzaktan eğitime geçtiklerinde kendilerini yalnız hissetmektedirler (Bozkurt, 2020). Öte yandan, öğretim elemanlarının uzaktan eğitime yönelik algılarını inceleyen başka bir çalışmada (Şahin İzmirli ve Mısırlı, 2015), öğretim elemanlarının algılarının olumlu olduğu yönünde sonuçlar sunulmaktadır. Üretilen metaforlara göre, öğretim elemanları uzaktan eğitimi çağın bir gereği olarak görmektedir. Erişim kolaylığı, öğrenme ve çare olma kategorileri diğer olumlu metafor gruplarıdır. Öğretim elemanları, uzaktan eğitimdeki etkileşim eksikliğini ise olumsuz olarak değerlendirmektedirler (Şahin İzmirli ve Mısırlı, 2015). Uzaktan eğitime yönelik farklı katılımcı türleri ile gerçekleştirilen bazı çalışmalarda elde edilen metafor kategorileri Tablo 1'de özetlenmiştir.

Tablo 1: Uzaktan Ĕ̆itim Kavramına Yönelik Oluşturulmuş Metafor Kategorileri

\begin{tabular}{|c|c|c|c|}
\hline $\begin{array}{l}\text { Kaleli Yılmaz ve } \\
\text { Güven (2015) }\end{array}$ & Çivril vd. (2017) & $\begin{array}{c}\text { Şahin İzmirli ve Mısırlı } \\
\text { (2018) }\end{array}$ & Bozkurt (2020) \\
\hline $\begin{array}{l}\text { Öğretmen Adayları } \\
(\mathrm{N}=150)\end{array}$ & $\begin{array}{l}\text { Üniversite Öğrencileri } \\
(\mathrm{N}=220)\end{array}$ & $\begin{array}{c}\text { Öğretim Elemanları } \\
(\mathrm{N}=52)\end{array}$ & $\begin{array}{l}\text { İlkokul Öğrencileri } \\
(\mathrm{N}=77)\end{array}$ \\
\hline $\begin{array}{l}\text { - İhtiyaca Yönelik } \\
\text { - Etkileşimsiz } \\
\text { - Çeşitlilik } \\
\text { - Kolay ulaşım } \\
\text { - Karmaşı } \\
\text { - İsteğe bağl1lık } \\
\text { - Duygusuz } \\
\text { - Gereklilik } \\
\text { - Faydalı } \\
\text { - Pahalı } \\
\text { - Sinırlı } \\
\text { - Kurallara uyma } \\
\text { - Değişken } \\
\text { - Yorucu } \\
\text { - S1kıcı } \\
\text { - Verimsiz } \\
\text { - Tamamlayıcı } \\
\text { - Bağımsız } \\
\text { - S1nırsız } \\
\text { - Bireysel hız } \\
\text { - Öğretici } \\
\text { - Hizlı } \\
\text { - Yön bulma } \\
\text { - Kapsamlı bilgi } \\
\text { - Planlı çalışma } \\
\text { - İmkâna bağl1lık } \\
\text { - Ekonomik } \\
\text { - İlgi çekici } \\
\text { - Herkese uygun } \\
\end{array}$ & $\begin{array}{l}\text { Esneklik } \\
\text { • Zaman Bağımsızlığı } \\
\text { • Mekân Bağımsızlığı } \\
\text { - Bireysel Farklılık } \\
\text { Erişilebilirlik } \\
\text { - Fırsat } \\
\text { • Mali durum } \\
\text { Eğitsel } \\
\text { - Akademik ve Mesleki } \\
\text { - Gelişim } \\
\text { - Öğretim Materyali } \\
\text { - Kolaylaştırıcı } \\
\text { - Eğitim Şekli } \\
\text { Etkileşim } \\
\text { - İletişim } \\
\text { - Sosyalleşme } \\
\text { Duyuşsal } \\
\text { - Motivasyon } \\
\text { - Memnuniyet } \\
\text { - Beklenti }\end{array}$ & $\begin{array}{l}\text { Olumlu } \\
\text { - Erişim kolaylığı } \\
\text { - Öğrenme } \\
\text { - Çağın gerekliliği } \\
\text { - Çare olma } \\
\text { Olumsuz } \\
\text { - Etkileşim eksikliği } \\
\text { - Yetersizlik }\end{array}$ & $\begin{array}{l}\text { Faydalı } \\
\text { - Kolaylaştırıcı } \\
\text { • Yaşam boyu ögrenme } \\
\text { Eğitim } \\
\text { - Öğretimsel bulunuşluk } \\
\text { - Yapılandırılmış öğrenme } \\
\text { - Topluluk hissi } \\
\text { Esneklik } \\
\text { - Özerklik } \\
\text { - Zaman ve mekân bağımsızlığı } \\
\text { Eğlenceli } \\
\text { - İçsel motivasyon } \\
\text { Teknoloji } \\
\text { - Erişilebilirlik } \\
\text { Etkileşim } \\
\text { - Yalnızlık duygusu } \\
\text { - Yapaylık } \\
\text { - Sosyalleşme } \\
\text { Zorunluluk } \\
\text { - Dişsal motivasyon } \\
\text { - İzolasyon } \\
\text { - İletişimsizlik } \\
\text { Yetersizlik } \\
\text { - Psikolojik uzaklık } \\
\text { - Kalite } \\
\text { Dijital Bölünme } \\
\text { - Eşitsizlik } \\
\text { Iletişsim } \\
\text { - Anındalık ve duyuşsal yakınlık }\end{array}$ \\
\hline
\end{tabular}


Tablo 1 incelendiğinde, uzaktan eğitime yönelik metafor analizi içeren çalışmalarda üretilen metaforların katılımcı grubuna göre farklılaştığı görülmektedir. Etkileşim boyutunun ise tüm katılımcı türlerinde, uzaktan eğitime yönelik olumsuz bir algıya sebep olduğu dikkat çekmektedir. Genel olarak alg1 çalışmaları değerlendirildiğinde, araştırma sonuçlarının bağlamsal olarak farklılaştığı söylenebilir. Nitekim uzaktan eğitim süreçlerini etkileyen pek çok faktör katılımcının içinde bulunduğu bağlamı oluşturmaktadır.

Alanyazında, uzaktan eğitim ile ilgili bilgi ve deneyimlerin, uzaktan eğitime yönelik bakış açılarını etkilediği ifade edilmektedir (Ateş ve Altun, 2008). 2019 yılının son ayında ortaya çıkıp 2020 yılında tüm dünyaya yayılan Covid-19 pandemisi ile pandeminin bulaş hızını yavaşlatmak için fiziksel temasın olabileceği yerler kapatılmış, tüm düzeylerden okullar da bu sürece dahil edilmiştir. Eğitimin devamlılı̆ğını sağlamak için tüm dünyada olduğu gibi Türkiye'de de üniversitelerde eğitimin büyük bir kısmı (acil) uzaktan eğitime (Bond, 2020; Bozkurt ve Sharma, 2020a; Durak vd., 2020; Hodges vd., 2020; Sezgin, 2021) geçiş yapmış ve tüm öğrenci-öğretim elemanları bu deneyimi yaşamışlardır. $\mathrm{Bu}$ süreçten yüksek öğretim öğrencileri de büyük ölçüde etkilenmiş (Aristovnik, Keržič, Ravšelj, Tomaževič ve Umek, 2020; Peters vd., 2020), çok kısa sürede yüz yüze eğitimden (acil) uzaktan eğitim sürecine geçiş yapmak zorunda kalmışlardır. Eğitimin uzaktan devam ettiği bu olağanüstü süreçte, pandemi ortamında uzaktan eğitime yönelik oluşan deneyimler kaybolmadan bu algının resmini çekmek önem arz etmektedir. Bu araştırmanın amacı, pandemi döneminde uzaktan eğitim yoluyla öğrenim görmüş/gören üniversite öğrencilerinin uzaktan eğitim kavramına ilişkin algılarını ve deneyimlerini metaforlar yoluyla ortaya koymaktır. Bu bağlamda aşağıdaki araştırma sorularına yanıt aranmaktadır:

1. Üniversite öğrencilerinin uzaktan eğitim kavramına ilişkin ürettikleri olumlu metaforlar nelerdir?

2. Üniversite öğrencilerinin uzaktan eğitim kavramına ilişkin ürettikleri olumsuz metaforlar nelerdir?

\section{YÖNTEM}

$\mathrm{Bu}$ çalışmada araştırma sorularına cevap bulabilmek için nitel yaklaşımlardan olgubilim (fenomenoloji) deseni kullanılmıştır. Olgubilim, tam anlamıyla kavrayamadığımı, derinlemesine bir anlayışa sahip olmadığımız olgulara odaklanır (Yıldırım ve Şimşek, 2013). Creswell'e (2013) göre olgubilim, bir olgu veya kavramla ilgili deneyimlerden meydana gelen ortak anlamın ifade eder. $\mathrm{Bu}$ araştırma kapsamında öğrencilerin uzaktan eğitim kavramına ilişkin algıları öğrencilerden toplanan metaforlar yoluyla toplanarak analiz edilmiştir. Metaforlar, bilinenden yola çıarak bilinmeyen bir alana bilgi aktarımı sağlayan (Lakoff ve Johnson, 2003) köprülerdir (Cortazzi ve Jin, 1999). Metaforlar, özellikle katılımcıyı yönlendirmeden, kendi özgün düşüncelerini ortaya çıkararak öznel verilerin elde edilmesini olanak sağlamaktadır (Güneş ve Fırat, 2016). Saban (2008), bireyin sahip olduğu bilgi, beceri ve tutumlar çerçevesinde bilinmeyene yaklaştığını ve bu bilinmeyen soyut bir kavram ise kavramı bilinen somut kavramlarla ilişkilendirerek açıkladığını belirtmektedir. Başka bir ifadeyle metaforlar, bir şeyin niteliğini ya da özelliğini açıklamak için başka bir şeyden yararlanma yoluyla oluşturulurlar.

\subsection{Araştırma Bağlamı}

Olgubilim olarak desenlenen bu araştırmanın bağlamı, Covid-19 pandemisinin ortaya çıktı̆̆ 2020-2021 eğitim öğretim yılında Türk yükseköğretim sisteminde kullanılan uzaktan eğitim uygulamalarıdır. Bu bağlamda araştırmada toplam 14 farklı üniversitede yükseköğretime devam eden 
öğrencilerden veri toplanmıştır. Çalışma, öğrencilerin pandemi süresince edindikleri uzaktan eğitim deneyimlerini ve bu deneyimleri sonucu oluşan uzaktan eğitim algılarını kapsamaktadır.

\subsection{Araştırma Grubu}

Araştırma kapsamında, 159 katılımcıya ulaşılarak veri toplanmıştır. Veri toplama aracında belirtilen yönergelere uygun olmayan 77 yanıt çıkarılarak 62 kadın ve 20 erkek öğrenci olmak üzere toplam 82 öğrenci ile araştırmaya devam edilmiştir. Araştırmaya katılan öğrencilere ait bilgiler Tablo 2'de sunulmaktadir.

Tablo 2: Araştırma Grubuna Ait Demografik Bilgiler

\begin{tabular}{|c|c|c|c|}
\hline Değișken & Seçenek & f & $\%$ \\
\hline \multirow{3}{*}{ Eğitim Seviyesi } & Lisans & 46 & 56 \\
\hline & Ön Lisans & 19 & 23.1 \\
\hline & Yüksek Lisans & 17 & 20.7 \\
\hline \multirow{4}{*}{ Yaş Grubu } & $18-20$ & 30 & 36.5 \\
\hline & $21-23$ & 32 & 39 \\
\hline & $24-26$ & 11 & 13.4 \\
\hline & 27 ve üzeri & 9 & 10.9 \\
\hline \multirow{2}{*}{$\begin{array}{l}\text { COVID } 19 \text { Öncesi Uzaktan } \\
\text { Eğitim Deneyimi }\end{array}$} & Var & 25 & 30.4 \\
\hline & Yok & 57 & 69.5 \\
\hline \multirow{14}{*}{ Üniversite } & Bayburt Üniversitesi & 47 & 57.3 \\
\hline & Anadolu Üniversitesi & 15 & 18.2 \\
\hline & Afyon Kocatepe Üniversitesi & 3 & 3.65 \\
\hline & Trabzon Üniversitesi & 3 & 3.65 \\
\hline & Recep Tayyip Erdoğan Üniversitesi & 3 & 3.65 \\
\hline & Karadeniz Teknik Üniversitesi & 2 & 2.43 \\
\hline & Ankara Yıldırım Beyazıt Üniversitesi & 2 & 2.43 \\
\hline & Hacettepe Üniversitesi & 1 & 1.21 \\
\hline & Sinop Üniversitesi & 1 & 1.21 \\
\hline & Kocaeli Üniversitesi & 1 & 1.21 \\
\hline & Orta Doğu Teknik Üniversitesi & 1 & 1.21 \\
\hline & Düzce Üniversitesi & 1 & 1.21 \\
\hline & Ondokuz Mayıs Üniversitesi & 1 & 1.21 \\
\hline & Atatürk Üniversitesi & 1 & 1.21 \\
\hline
\end{tabular}

\subsection{Veri Toplama Aracı, Verilerin Toplanması ve Analizi}

Öğrencilerin uzaktan eğitim kavramına ilişkin algıları, "Uzaktan eğitim .... gibidir. Çünkü...." cümlesini tamamlamaları ile elde edilmiştir. Forceville'ye (2002) göre bir metafor ilişkisi; metafor konusu, kaynağı ve nedeni olmak üzere üç bileşenden oluşmaktadır. Bu cümledeki "gibidir” kavramı ile, metafor konusu ve kaynağı arasındaki bağlantı, "çünkü” kavramı ile de katılımcıların metafor tanımlarının sebepleri sunulmaktadır (Saban, 2008). Araştırmada, veri toplamak amacıyla çevrimiçi anket formu hazırlanmıştır. Formda öğrenci ve öğretim elemanlarına metafor olgusu, birkaç örnekle birlikte açıklandıktan sonra "Uzaktan eğitim .... gibidir. Çünkü... ” ifadesini tamamlamaları istenmiştir. Toplanan veriler içerik analizi ile çözümlenmiştir. İçerik analizi sürecinde, verilerin kodlanarak kategorize edildiği sistematik adımlar izlenmiştir (Büyüköztürk, 2010). Elde edilen bulgular frekans ve yüzde şeklinde ifade edilmiştir. Veri toplama sürecinde Bayburt Üniversitesi Etik Kurulu'ndan 12.03.2021 tarihli 2021/51 sayılı karar ile etik onayı alınmıştır. 


\subsection{Geçerlik ve Güvenirlik}

Toplanan verilerin geçerlik ve güvenirliklerini sağlamak için Yıldırım ve Şimşek (2013) nitel araştırmaya özgü kavramların (inandırıcılık, aktarılabilirlik, tutarlılık ve teyit edilebilirlik) kullanmasını önermektedir. Bu bağlamada inandırıcılığı sağlamak için elde edilen veriler iki bağımsız alan uzmanı tarafından da incelenmiştir. Ayrıca, veriler gönüllülük esasına göre toplanmıştır. Aktarılabilirlik için seçilen yöntemin gerekçesi, örneklem özellikleri ve araştırma süreci detaylı bir şekilde açıklanmıştır. Tutarlılığı sağlamak için veriler kayıt altına alınmış ve tutarlılık açısından iki alan uzmanı tarafından değerlendirilmiştir. Teyit edilebilirlik için ise tüm ham veriler ve kodlamaları dijital ortamda kayıt altına alınmıştır.

\subsection{Sinirlılıklar}

$\mathrm{Bu}$ çalışma birtakım sınırlılıklara sahiptir. Öncelikle çalışma verileri Covid-19 pandemisi süresince toplanmıştır. Dolayısıyla çalışma verileri, katılımcıların pandemi sürecinde edindikleri (acil) uzaktan eğitim deneyimlerini yansıtırken genel anlamda yapılan planlı ve kapsamlı uzaktan eğitim çalışmalarını yansıtmamaktadır. Bu sınırlılığın yanı sıra çalışma verileri yükseköğretimde farklı düzeylerde (ön lisans, lisans ve yüksek lisans) eğitime devam eden öğrencilerden toplanmıştır. Her ne kadar bu çalışma bulguları yorumlanırken bu ayrım temel alınmasa da farklı öğrenim düzeylerinde farklı araştırma bulguları çıkabileceği araştırmacılar tarafından kabul edilmektedir. Son olarak toplam 82 katılımcıdan 25 öğrencinin daha önceden uzaktan eğitim deneyimi olduğu, 57 öğrencinin ise ilk uzaktan eğitim deneyimlerinin pandemi süresince yapılan uygulamalarla sınırlı olduğunun altı çizilmelidir.

\section{BULGULAR VE TARTIŞMA}

Araştırmaya katılan 82 öğrenci, 68 olumlu ve 81 olumsuz metafor üretmişlerdir. Metaforlar, kategori ve temalar altında analiz edilerek sunulmuştur.

\subsection{Olumlu Metaforlara İlişkin Bulgular}

Olumlu metaforlar; "esneklik", "kullanışl1lık", "öğrenci katılımı” ve "uygunluk” olmak üzere 4 tema altında gruplandırılmıştır. Temalar altında metaforlara ilişkin kategoriler yer almaktadır. "Esneklik" temasında, "rahatlık", "zaman esnekliği”" ve "mekân esnekliği” kategorileri; "kullanışl1lık" temasında, "zengin bilgi kaynağı", "kolaylaştırıcı", "planlı”, "erişilebilir”, "firsat eşitliği”, "kapsamlı" ve "iş birliği” kategorileri; "öğrenci katılımı" temasında, "öz-düzenleme", "verimlilik" ve "motivasyon" kategorileri; "uygunluk "temasında ise "alternatif" ve "ihtiyaç" kategorileri bulunmaktadır. Tema ve kategorilere ilişkin olumlu metaforlar Tablo 3 'te sunulmaktadır.

Tablo 3: Olumlu Metafor Kategori ve Temalart

\begin{tabular}{|c|c|c|c|c|c|}
\hline Tema & Kategori & Metafor & $\mathbf{f}$ & $\%$ & Örnek Metafor \\
\hline $\begin{array}{l}\text { Esneklik } \\
(\mathrm{f}=41)\end{array}$ & Rahatl1k & $\begin{array}{l}\text { anne kucağı (2), yatak (4), } \\
\text { beş yıldızlı otel, yalnız } \\
\text { yaşamak, ev (3), yastık, } \\
\text { pijama (2), sağlıklı, iyi (2), } \\
\text { sessizlik, değerli zaman, } \\
\text { teknolojik, konfor, az } \\
\text { zahmetle çok kazanç, rahat } \\
\text { mekân }\end{array}$ & 23 & 28 & $\begin{array}{l}\text { "Anne kucağı gibidir. Çünkü evden tüm } \\
\text { derslere ulaşabiliyoruz, notlar veriliyor, } \\
\text { ev rahatlığ1 var." }\end{array}$ \\
\hline
\end{tabular}


Tablo 3 (Devam): Olumlu Metafor Kategori ve Temalarl

\begin{tabular}{|c|c|c|c|c|c|}
\hline Tema & Kategori & Metafor & $\mathbf{f}$ & $\%$ & Örnek Metafor \\
\hline & $\begin{array}{l}\text { Zaman } \\
\text { Esnekliği }\end{array}$ & $\begin{array}{l}\text { koltuk, film (2), kitap (2), } \\
\text { zamanı durdurmak, tv, } 15 \\
\text { dakikada bir gelen banliyö } \\
\text { treni, çalışan bir kişi }\end{array}$ & 9 & 10.9 & $\begin{array}{l}\text { "Kitap gibidir. Çünkü isteğimiz zaman } \\
\text { ders içeriğine erişebiliriz." }\end{array}$ \\
\hline & $\begin{array}{l}\text { Mekân } \\
\text { Esnekliği }\end{array}$ & $\begin{array}{l}\text { kitap, açıköğretim ( } 3) \text {, nefes } \\
\text { almak, firsat, yakından } \\
\text { eğitim, dost, köprü }\end{array}$ & 9 & 10.9 & $\begin{array}{l}\text { "Fırsat gibidir. Çünkü aile evinin } \\
\text { sıcaklığıyla sınırsız web kaynağı } \\
\text { aracıllığıyla öğrenimi kolaylaştırır." }\end{array}$ \\
\hline \multirow{7}{*}{$\begin{array}{l}\text { Kullanışl11ık } \\
(\mathrm{f}=22)\end{array}$} & $\begin{array}{l}\text { Zengin Bilgi } \\
\text { Kaynağı }\end{array}$ & $\begin{array}{l}\text { kütüphane, meyve bahçesi, } \\
\text { gökkuşağı, güneş, } \\
\text { ansiklopedi, kar }\end{array}$ & 6 & 7.3 & $\begin{array}{l}\text { "Kütüphane gibidir. Çünkü içinde her } \\
\text { türlü bilgi barındırır." }\end{array}$ \\
\hline & Kolaylaştırıcı & $\begin{array}{l}\text { nehir, ingiliz anahtarı, } \\
\text { anayol, makine, ulaşım }\end{array}$ & 5 & 6 & $\begin{array}{l}\text { "Nehir gibidir. Çünkü ilerlememiz için } \\
\text { bizi destekler." }\end{array}$ \\
\hline & Planlı & $\begin{array}{l}\text { merkezi yönetim, çalar saat, } \\
\text { iyi eğitim, yüz yüze eğitim }\end{array}$ & 4 & 4.8 & $\begin{array}{l}\text { "Merkezden yönetim gibidir. Çünkü belli } \\
\text { bir düzeni var." }\end{array}$ \\
\hline & Erişilebilir & aile (2), telefon (2) & 4 & 4.8 & $\begin{array}{l}\text { “Telefon gibidir. Çünkü ulaşı1ması } \\
\text { kolaydır.” }\end{array}$ \\
\hline & Fursat Eşitliği & eşitlik & 1 & 1.21 & $\begin{array}{l}\text { "Eşitlik gibidir. Çünkü bu sayede firsat } \\
\text { eşitliği sağlanmış oldu." }\end{array}$ \\
\hline & Kapsamlı & engin bir deniz & 1 & 1.21 & $\begin{array}{l}\text { "Engin bir deniz gibidir. Çünkü hem } \\
\text { öğrenenin hem de öğretenin efor } \\
\text { göstererek bir yere ulaştığ özgür bir } \\
\text { alandır." }\end{array}$ \\
\hline & İş Birliği & imece & 1 & 1.21 & $\begin{array}{l}\text { "İmece gibidir. Çünkü ödevlerde } \\
\text { yardımlaşma oluyor." }\end{array}$ \\
\hline \multirow{3}{*}{$\begin{array}{l}\text { Öğrenci } \\
\text { Katılımı } \\
(\mathrm{f}=11)\end{array}$} & $\begin{array}{l}\text { Öz- } \\
\text { Düzenleme }\end{array}$ & $\begin{array}{l}\text { çiçek, ağaç, kendini } \\
\text { bulmak, kendinin öğretmeni } \\
\text { olmak, ateş, kütüphane, özel } \\
\text { ders }\end{array}$ & 7 & 8.5 & $\begin{array}{l}\text { "Kişinin kendini bulması gibidir. Çünkü } \\
\text { insan her şeyi kendisi araştırarak } \\
\text { öğrenme çabası içerisinde ve ev } \\
\text { hayatıyla uyumu iyi kurması gerekir." }\end{array}$ \\
\hline & Verimlilik & tarayıc1, youtube & 2 & 2.43 & $\begin{array}{l}\text { "Tarayıcı gibidir. Çünkü } 5 \text { dakikada } \\
\text { sayfalarca bilgiye bakabilirsin.” }\end{array}$ \\
\hline & Motivasyon & çikolata, tatlı & 2 & 2.43 & "Tatlı gibidir. Çünkü mutlu eder." \\
\hline \multirow[t]{3}{*}{$\begin{array}{l}\text { Uygunluk } \\
(\mathrm{f}=8)\end{array}$} & Alternatif & $\begin{array}{l}\text { yardımcı, çınar ağacı, hazır } \\
\text { yemek, gezegen, sanal } \\
\text { yolculuk, bedelli askerlik }\end{array}$ & 6 & 7.3 & $\begin{array}{l}\text { "Bir gezegen gibidir. Çünkü Dünya'da } \\
\text { bazı imkanlara ulaşmak zorlaştığında } \\
\text { neredeyse sınırsız olanaklar sunar." }\end{array}$ \\
\hline & İhtiyaç & su, ilaç & 2 & 2.43 & $\begin{array}{l}\text { "Su gibidir. Çünkü yoklukta tek ihtiyaç } \\
\text { olabilir." }\end{array}$ \\
\hline & & & 82 & 100 & \\
\hline
\end{tabular}

\subsubsection{Esneklik Teması}

Olumlu metaforlar içerisinde en fazla metafor oluşturulan tema, esneklik temasıdır $(n=41)$. Esneklik teması; rahatlık, zaman esnekliği ve mekân esnekliği kategorilerini kapsamaktadır. Öğrenciler uzaktan eğitimin rahat bir süreç olduğunu düşünmektedirler. Bu bağlamda, "pijama”, "ev”, "yatak” ve "anne kucağı" gibi metaforlar üretilmiştir. Öğrenciler uzaktan eğitimi rahat olarak görmekle birlikte, uzaktan eğitimin kendilerine zaman ve mekân esnekliği sağladığını da belirtmektedirler. Özellikle zaman esnekliği bağlamında derslerin tekrar izlenebilmesini işaret ederek "kitap" ve "film" gibi metaforlar üretmişlerdir. Alanyazında, zamansal ve mekânsal esneklik uzaktan eğitimin doğasında olan bir özellik olarak ifade edilmektedir (Moore ve Kearsley, 2012; Valentine, 2002). Hem ilkokul öğrencileri (Bozkurt, 2020) hem de üniversite öğrencilerinin (Çivril vd., 2017) uzaktan eğitime yönelik algılarını inceleyen benzer çalışmalarda esnekliğe yönelik metaforlar ve kategoriler bulunmaktadır. 


\subsubsection{Kullanışlılık Teması}

Kullanışlılık temasında (n=23), "zengin bilgi kaynağı", "kolaylaştırıcı", "planlı", "erişilebilir", "masrafsız", "firsat eşitliği”, "kapsamlı" ve "iş birliğì" kategorileri elde edilmiştir. Öğrencilere göre uzaktan eğitimde sunulan öğrenme kaynakları daha fazla çeşitlilik göstermektedir. $\mathrm{Bu}$ doğrultuda "gökkuşağı" metaforunu kullanan K40, "Uzaktan eğitim gökkuşağ gibidir. Çünkü çok farklı şekillerde çok farklı bilgiler edinmemize ve bunu karşımızdakilere bilgisayar başında bile aktarma firsatı da bize sunuyor." ifadesini belirtmiştir. Bu temayı destekler nitelikte olan Arkorful ve Abaidoo (2015) uzaktan eğitimin farklı bilgi kaynaklarına sağladığı erişim olanaklarının uzaktan eğitimin niteliğini güçlendirdiğini ifade etmektedir.

Bazı öğrenciler de "nehir", "İngiliz anahtarı", "anayol”, "makine”, "ulaşım” metaforlarını üreterek uzaktan eğitimin öğrenmeyi kolaylaştırdığını ifade etmişlerdir. K80, bu kolaylığı "Uzaktan eğitim İngiliz anahtarı gibidir. Çünkü faydalanmasını bilen için kurtarıcıdır." görüşüyle belirtmektedir. Bu çalışma kapsamında "telefon" ve "aile" metaforlarını kullanan 4 öğrenci, uzaktan eğitimin kolay erişilebilir olduğunu düşünmektedir. Ayrıca, "engin bir deniz" metaforunu kullanan K82 ise uzaktan eğitimin geniş kapsamına dikkat çekmektedir.

Öte yandan "planlı” teması kapsamında uzaktan eğitim için, "merkezi yönetim”, “çalar saat”, "iyi eğitim", "yüz yüze eğitim” metaforlarının tercih edildiği görülmektedir. Öğrenciler bu metaforlarla uzaktan eğitimin planlı işleyişine işaret etmektedirler. Uzaktan eğitimi yüz yüze eğitime benzeten K50, "Uzaktan eğitim, yüz yüze [eğitim] gibidir. Çünkü derslerimizi eksiksiz işliyoruz." gerekçesini sunmaktadır. İlgili alanyazında, uzaktan eğitimin planlı ve sistematik olma özelliğine vurgu yapılmaktadır (Greenberg,1998; Moore ve Kearsley, 2012) ve bu durum bu araştırma bağlamında ortaya çıkan tema ile benzer niteliktedir.

\subsection{3. Öğrenci Katılımı Teması}

Öğrenci katılımı temasında; "öz-düzenleme", "verimlilik" ve "motivasyon" kategorileri bulunmaktadır. Pandemi sebebiyle uzaktan eğitim görmekte olan katılımcılar ( $\mathrm{n}=7$ ), öğrenme süreçlerine daha fazla katılım gösterdiklerini düşünmektedirler. Ayrıca "verimlilik" kategorisinde bulunan "tarayıcı" ve "YouTube" metaforlarıyla öğrenciler, pek çok bilgiye hızlı bir şekilde ulaşabildiklerini belirtmektedirler. Katılımc1 2 öğrenci uzaktan eğitimi "çikolata" ve "tatlı" metaforlarıyla nitelendirerek motivasyon faktörüne işaret etmektedir. Howland ve Moore'a (2002) göre, öz-yönetim (self management), öz-izleme (self monitoring) ve motivasyon kavramlarının uzaktan eğitimde yüz yüze eğitimden daha önemli olduğunu ifade etmektedirler. Benzer bir şekilde uzaktan eğitimde öğrencilerin öz-yeterlilikleri öğrencilerin akademik performanslarını da etkilemekte (Hobson ve Puruhito, 2018), yaratıcılık, performans ve katılım gibi değişkenleri de doğrudan etkilemektedir (Schunk vd., 2008). İlgili alanyazındaki bulgular ve ortaya çıkan metaforlar öğrenci katılımını sağlamak için motivasyonu sağlamanın önemini vurgulamaktadır.

\subsubsection{Uygunluk Temast}

Çalışmaya katılan bazı öğrenciler $(n=6)$ uzaktan eğitimi yüz yüze eğitime bir alternatif olarak algılamaktadır. Bu bağlamda, "gezegen”, "sanal yolculuk", "hazır yemek” gibi metaforlar üretmişlerdir. Uzaktan eğitimin pandemi sürecindeki kullanımına ilişkin K18, "Uzaktan eğitim yardımcı gibidir. Çünkü bu zamanlarda en uygun yapılabilecek eğitimdir." metaforunu üretmiştir. "Su" ve "ilaç" 
metaforlarını üreten 2 öğrenci ise uzaktan eğitimin ihtiyaç olduğunu düşünmektedir. Bu durum Naidu'nun (2016) bulgularını doğrular niteliktedir. Naidu (2016) ana akım eğitimin bir parçası olan uzaktan eğitimin bilgiye erişimde sağladığı esnek çözümlerin birçok öğrenci için iyi bir alternatif olduğunu vurgulamaktadır. Pandemi ile zorunlu bir şekilde tecrübe edilen uzaktan eğitim süreçlerinin kriz anında sağladığı alternatif kanalların yükseköğretim öğrencilerinin bu yöndeki algılarını güçlendirdiği söylenebilir.

\subsection{Olumsuz Metaforlara İlişkin Bulgular}

Olumsuz metaforlar; “"̈ğretim süreci”, "öğrenci durumu”, "kullanışl1l1k”, “ölçme-değerlendirme” ve "acil uzaktan öğretim" olmak üzere 5 tema olarak gruplandırılmıştır. Temalar altında metaforlara ilişkin ilgili kategoriler yer almaktadır. Öğretim süreci temasında "düşük etki" ve "sınırlı etkileşim" kategorileri; öğrenci durumu temasında "dijital yeterlilikler", "motivasyon kaybı", "topluluk hissi", "öğrenme sorumluluğu", "yorucu" ve "tembellik" kategorileri; kullanışl1lık temasında "gelecek belirsizliği", "maliyet", "eşitsizlik" ve "ekran süresi" kategorileri; ölçme değerlendirme temasında "sinav güvenliği" ve "fazla ödev" kategorileri; acil uzaktan öğretim temasında ise "eğitimin her kademesini etkileme" ve "acil dönüşüm” kategorileri bulunmaktadır. Bu temalara ilişkin olumsuz metaforlar Tablo 4'te sunulmaktadır.

Tablo 4: Olumsuz Metafor Kategori ve Temalarl

\begin{tabular}{|c|c|c|c|c|c|}
\hline Tema & Kategori & Metafor & $\mathbf{f}$ & $\%$ & Örnek Metafor \\
\hline \multirow[t]{2}{*}{$\begin{array}{l}\text { Öğretim Süreci } \\
(\mathrm{f}=39)\end{array}$} & Düşük Etki & $\begin{array}{l}\text { kumanda, taş dolu kavanoz, } \\
\text { çürük meyve, tek kanatlı kuş, } \\
\text { uzaktan kumandalı araba, soğuk } \\
\text { kahve, yapay, akvaryumdaki } \\
\text { balık, açıköğretim (2), atom } \\
\text { bombası, şimşek, serap, duman, } \\
\text { havasız lastik, kış güneşi, acı } \\
\text { kahve, parol, tuzsuz yemek, } \\
\text { çorak toprak, pamuk şekeri, } \\
\text { yapay çiçek, müzik, solmuş } \\
\text { çiçek, çile, sıradan bir ders, } \\
\text { tahtasız ders işlemek }\end{array}$ & 27 & 32.9 & $\begin{array}{l}\text { "Çorak toprak gibidir. Çünkü ne } \\
\text { kadar ekip biçsen de verim } \\
\text { alamazsın.” }\end{array}$ \\
\hline & $\begin{array}{l}\text { Sinırlı } \\
\text { Etkileşim }\end{array}$ & $\begin{array}{l}\text { kış mevsimi, görmeden sevmek, } \\
\text { ayna, yapay zekâ, robotik } \\
\text { iletişim, mesafe, k1sıtlı, soğuk } \\
\text { çay, asosyal, sinema, aşk, } \\
\text { yalnızlık }\end{array}$ & 12 & 14.6 & $\begin{array}{l}\text { "Soğuk çay gibidir çünkü yüz yüze } \\
\text { eğitim gibi sicak bir ortam yoktur." }\end{array}$ \\
\hline \multirow{6}{*}{$\begin{array}{l}\text { Öğrenci } \\
\text { Durumu } \\
(\mathrm{f}=23)\end{array}$} & $\begin{array}{l}\text { Dijital } \\
\text { Yeterlilikler }\end{array}$ & $\begin{array}{l}\text { bozuk saat, modem, internet } \\
\text { sıkıntısı, ön koşullu program, } \\
\text { karikatür, boşa kürek çekmek, } \\
\text { para }\end{array}$ & 7 & 8.5 & $\begin{array}{l}\text { "Önkoşul gerektiren programlar } \\
\text { gibidir. Çünkü eğitim için internet ve } \\
\text { interneti kullanabileceğiz bir cihaz } \\
\text { gerektirir." }\end{array}$ \\
\hline & $\begin{array}{l}\text { Motivasyon } \\
\text { Kayb1 }\end{array}$ & $\begin{array}{l}\text { yarış, film tekrarı, ceza, dikkat } \\
\text { dağıtıcı, boş bakmak }\end{array}$ & 5 & 6 & $\begin{array}{l}\text { "Boş bakmak gibidir. Çünkü } \\
\text { yeterince adapte olunamıyor." }\end{array}$ \\
\hline & $\begin{array}{l}\text { Topluluk } \\
\text { Hissi }\end{array}$ & $\begin{array}{l}\text { ormanda terkedilmek, yeni } \\
\text { alınan ayakkabı, deniz, altın } \\
\text { kafesteki kuş }\end{array}$ & 4 & 4.8 & $\begin{array}{l}\text { "Yeni alınan ayakkabı gibidir. Çünkü } \\
\text { bir türlü alışamazsın." }\end{array}$ \\
\hline & $\begin{array}{l}\text { Öğrenme } \\
\text { Sorumluluğu }\end{array}$ & $\begin{array}{l}\text { kendi hayatını yönetemeyen } \\
\text { kişi, çocuğa verilen sorumluluk, } \\
\text { meteor yağmuru }\end{array}$ & 3 & 3.6 & $\begin{array}{l}\text { "Kendi hayatını yönetemeyen kişi } \\
\text { gibidir. Çünkü başarılı olma şansı çok } \\
\text { düşüktür." }\end{array}$ \\
\hline & Yorucu & bisiklet, dağ & 2 & 2.4 & "Bisiklet gibidir. Çünkü bizi yorar." \\
\hline & Tembellik & koala, pas & 2 & 2.4 & $\begin{array}{l}\text { "Pas gibidir. Çünkü işlevsiz hale } \\
\text { geliriz." }\end{array}$ \\
\hline
\end{tabular}


Tablo 4 (Devam): Olumsuz Metafor Kategori ve Temaları

\begin{tabular}{|c|c|c|c|c|c|}
\hline Tema & Kategori & Metafor & f & $\%$ & Örnek Metafor \\
\hline \multirow{4}{*}{$\begin{array}{l}\text { Kullanışlilık } \\
(\mathrm{f}=11)\end{array}$} & $\begin{array}{l}\text { Gelecek } \\
\text { Belirsizliği }\end{array}$ & $\begin{array}{l}\text { gerilim filmi, farsız araba, covid } \\
\text { aşısı, içeriği bilinmeyen erzak } \\
\text { kutusu }\end{array}$ & 4 & 4.8 & $\begin{array}{l}\text { "Gerilim filmi gibidir. Çünkü her an } \\
\text { ne olacağı belli değildir." }\end{array}$ \\
\hline & Maliyet & fatura, lüks araba, masraf & 3 & 3.6 & $\begin{array}{l}\text { "Lüks araba gibidir. Çünkü } \\
\text { pahalıdır." }\end{array}$ \\
\hline & Eşitsizlik & $\begin{array}{l}\text { bozuk terazi, firsat eşitsizliği, } \\
\text { adaletsiz }\end{array}$ & 3 & 3.6 & $\begin{array}{l}\text { "Bozuk terazi gibidir. Çünkü } \\
\text { imkanların yetersizliğinden dolayı } \\
\text { eğitimde eşitsizlik artmaktadır." }\end{array}$ \\
\hline & Ekran Süresi & kum saati & 1 & 1.2 & $\begin{array}{l}\text { "Kum saati gibidir. Çünkü zamanın } \\
\text { bilgisayar başında nasıl geçtiğini } \\
\text { anlamıyoruz." }\end{array}$ \\
\hline \multirow{2}{*}{$\begin{array}{l}\text { Ölçme } \\
\text { Değerlendirme } \\
(\mathrm{f}=5)\end{array}$} & $\begin{array}{l}\text { Sinav } \\
\text { Güvenliği }\end{array}$ & $\begin{array}{l}\text { hırsızlık, dalkavuk, işçi, } \\
\text { adaletsiz }\end{array}$ & 4 & 4.8 & $\begin{array}{l}\text { "İşçi gibidir. Çünkü çalışmanın } \\
\text { hakkını alamazsın." }\end{array}$ \\
\hline & Fazla Ödev & gül dikeni & 1 & 1.2 & $\begin{array}{l}\text { "Gül dikeni gibidir. Çünkü çok } \\
\text { verilen ödevler gözlerimize, aklımıza } \\
\text { ve kalbimize diken gibi batmaktadır." }\end{array}$ \\
\hline \multirow{3}{*}{$\begin{array}{l}\text { Acil Uzaktan } \\
\text { Öğretim }(\mathrm{f}=4)\end{array}$} & $\begin{array}{l}\text { Her Seviyeyi } \\
\text { Etkileme }\end{array}$ & sarmaşık, mecburiyet & 2 & 2.4 & $\begin{array}{l}\text { "Sarmaşık gibidir. Çünkü hepimizi } \\
\text { çok sıkı sarıp sarmaladı." }\end{array}$ \\
\hline & Acil Dönüşüm & $\begin{array}{l}\text { davetsiz misafir, elektrik } \\
\text { kesintisi }\end{array}$ & 2 & 2.4 & $\begin{array}{l}\text { "Elektrik kesintisi gibidir, sizi ikiye } \\
\text { böler. Çünkü devam etmek } \\
\text { zorunluluğu ile sizi bağlayan bir } \\
\text { dünyanız vardır." }\end{array}$ \\
\hline & & & 82 & 100 & \\
\hline
\end{tabular}

\subsection{1. Ö̆̆retim Süreci Teması}

Öğrencilerin uzaktan eğitime yönelik olumsuz metaforları incelendiğinde, en fazla metafor üretilen temanın "öğretim süreci” olduğu görülmektedir. Bu çerçevede "düşük etki” ve "sınırlı etkileşim” kategorileri yer almaktadır. Öğrencilere göre uzaktan eğitimde etkili bir öğrenme gerçekleşmemektedir. Öğrenciler, "çürük meyve", "yapay çiçek", "havasız lastik", "çorak toprak” gibi metaforlarla bu görüşü ortaya koymuşlardır (Tablo 4). "Serap" metaforunu kullanan K38, "Uzaktan eğitim, çölde görülen serap gibidir. Çünkü var olduğunu görüyorum ama aslında hiçbir şey yok." şeklinde gerekçe sunmaktadır. Uzaktan eğitim ve geleneksel yüz yüze eğitimi bu bağlamda akademik başarı yönüyle kıyaslayan Russell (1997), 1928-1997 yılları arasında yapılan ilgili çalışmaları inceleyerek uzaktan eğitim ile yüz yüze eğitim arasında bir fark olmadığını ortaya koymuştur. Benzer amaçla 1995-2004 yılları arasındaki çalışmaları analiz eden Jahng, Zhang ve Zhang (2007) de uzaktan eğitim ve yüz yüze eğitim arasında başarı farkı olmadığı sonucunu yinelemektedir. Ancak pandemi sürecindeki acil uzaktan öğretim uygulamaları dikkate alındığında, yüz yüze eğitimin uzaktan eğitimde devam ettirilmeye çalışıldığı, başka bir ifadeyle yüz yüze eğitimin uzaktan eğitim süreçlerinde taklit edildiği ve bu durumun beraberinde çeşitli sorunları getirdiği belirtilmektedir (Bond, 2020; Bozkurt vd., 2020). Bu bağlamda ortaya çıkan sorunların, öğrencilerin "düşük etki" metaforlarına sebep olduğu söylenebilir. Ayrıca, uzaktan eğitimin uygulama gerektiren teknik derslerde etkili ve verimli olmadığ 1 yönünde araştırma sonuçları da bulunmaktadır (Horzum, 2003). Jung ve Rha'ya (2000) göre de uzaktan eğitimin etkililiği; kurumsal işleyiş, teknik altyapı, öğretim tasarımı, kullanılan platform, etkileşim düzeyi, öğrenci ve öğretmen yeterlilikleri gibi çeşitli faktörlere bağlıdır. Dolayısıyla belirtilen her faktöre yönelik stratejik düzenlemeler yapılması gerekliliği bu çalışma bulguları ile paralellik göstermektedir.

"Sınırlı etkileşim" kategorisi, öğrencilerin uzaktan eğitimdeki etkileşimin yeterli olmadığ yönünde sundukları metaforları kapsamaktadır. Etkileşim yetersizliğine dikkat çeken K71, "Uzaktan eğitim robotik iletişim gibidir çünkü derse görüntü ve ses olmadan katılım gösterildiğinde kendi kendine konuşuyor olmaktan öteye gitmemektedir." görüşünde "robotik iletişim" metaforunu kullanmıştır. 
Benzer çalışmalarda da uzaktan eğitimde iletişim ve etkileşim eksiklikleri, olumsuz görüş kaynağı olarak sunulmaktadır (Fidan, 2017). Uzaktan eğitimde etkileşim ve iletişim, başarılı bir öğrenme deneyimi için gerekli bir bileşen olarak görülmektedir (Hirumi, 2002; Moore, 1989). Alanyazındaki uzaktan eğitime yönelik metaforik algı çalışmalarında da etkileşim boyutu bu çalışmanın bulgularına benzer olarak hem K12 düzeyinde hem de yükseköğretim düzeyinde karşımıza çıkmaktadır (Bozkurt, 2020; Çivril vd., 2018; Kaleli Y1lmaz ve Güven, 2015). Anderson (2003) ve Moore (1989), uzaktan eğitimde anlamlı bir öğrenme için; öğrenci-öğrenci, öğrenci-öğretmen ve öğrenci içerik etkileşiminin artırılması gerektiğini ifade etmektedir. Nitekim, etkileşimden doğan topluluk hissi ve bilişsel öğrenme arasında anlamlı pozitif ilişki ortaya koyan çalışmalar da bulunmaktadır (Rovai, 2002). Bu noktada, öğrencinin fazla mesaj göndermesi veya sosyal etkileşimin yüksek olmasının anlamlı öğrenmeyi garantilemediği belirtilerek çevrimiçi katılımın niteliğine de dikkat çekilmektedir (Garrison ve Cleveland-Innes, 2005).

\subsubsection{Kullanışlılık Teması}

Metafor yoluyla toplanan veriler incelendiğinde, pandemi sürecinde uzaktan eğitime acil olarak geçişin öğrenci görüş̧lerine yansıdığı görülmektedir. Toplamda 4 öğrenci uzaktan eğitimi, belirsiz olarak algılamaktadır. "Farsız araba" metaforunu kullanan K44, "Farsız bir araba gibidir çünkü ne kadar yol alırsak alalım karanlık bir yolda ne kadar bir yol çizdiğimiz belli olmaz." ifadesiyle belirsizliğe dikkat çekmektedir. Bunun yanı sıra 3 öğrenci ise uzaktan eğitimin olumsuz yanının, maliyet olduğunu düşünmektedir. Bazı öğrenciler de maliyetten kaynaklanan eşitsizliklere yönelik metaforlar üretmişlerdir. "Eşitsizlik" kategorisinde öğrenciler $(n=4)$ uzaktan eğitimin bazı eşitsizlikleri ortaya çıkardığını düşünmektedirler. Bu çerçevede "bozuk terazi”, "firsat eşitsizliği”, "adaletsiz" metaforları üretilmiştir. Belirtilen bu eşitsizliğe dikkat çeken Anderson'a (2020) göre, pandemi ile başlayan uzaktan eğitim süreci; interneti veya dijital cihazı olan-olmayan, kendi öğrenmesini yönetebilen-yönetemeyen, ailesi tarafından eğitimine zaman ayrılan-ayrılmayan öğrenciler arasında var olan eşitsizliği gün yüzüne çıkarmış ve daha belirgin bir hale getirmiştir.

Temanın son kategorisinde ise 1 öğrenci "kum saati” metaforuyla ekran karşısında geçen zamanı uzaktan eğitimin olumsuz yönü olarak nitelemektedir. Alanyazında Türkiye'deki üniversite öğrencilerine ait ekran sürelerinin Covid-19 salgınıyla birlikte anlamlı düzeyde artış gösterdiği ifade edilmektedir (Öz Ceviz vd., 2020). Bu bağlamda ders saatlerini yüz yüze eğitime eşdeğer tutmaya çalışmak yerine öğrenci memnuniyeti ve verimliliği de dikkate alarak düzenlemeler yapılması ihtiyaç duyulan bir gereksinim olarak ortaya çıkmaktadır. Bu bulguları destekler nitelikte dijital yorgunluk ve dijital tükenmişlik kavramı ilgili alanyazında da sıklıkla ele alınmaktadır (Bozkurt ve Sharma, 2020a; Sklar, 2020).

\subsection{3. Öğrenci Durumu Teması}

"Dijital Yeterlilikler" kategorisinde, uzaktan eğitimin teknik ihtiyaçlar ve dijital beceriler gerektirdiği yönündeki metaforlara yer verilmiştir. Öğrencilerin uzaktan eğitim sürecini etkili yönetebilmek için dijital yeterliliklere (Ala-Mutka, 2011; Howell, 2012) sahip olmasının yanı sıra bu yeterliliklerini sergileyebilecekleri araç ve altyapı olanaklarına sahip olmaları da önemlidir. Teknolojik ekipmanların ve altyapının yetersiz olması, uzaktan eğitimin gelişimi önünde büyük bir engel olarak ifade edilmektedir (Alvarez, 2020). Can (2020), özellikle pandemi ile birlikte uzaktan eğitimde derslere katılımı etkileyen faktörlerden biri olarak bu dijital yeterliliklere sahip olunmasını işaret etmektedir. 
“Öğrenci durumu” temasında uzaktan eğitime yönelik algılanan olumsuz metaforlar öğrenci bağlamında ele alınmaktadır. Bazı öğrenciler ( $n=5)$, uzaktan eğitim sürecinde motivasyon ile ilgili sorunları gerekçe göstererek olumsuz metaforlar sunmuşlardır. Uzaktan eğitimi "dikkat dağıtıcı" olarak nitelendiren K79, "Uzaktan eğitim dikkat dağıtıcı gibidir. Çünkü uzun süre ekran karşısında sanal bir ortamda eğitim almaya çalışmak, dikkati sabit tutmak kişileri zorlayabilir." ifadesini kullanmıştır. Bu noktada karşımıza öğrenme motivasyonu ve motivasyonunun sürekliliği çıkmaktadır. Öğrenci motivasyonunun, uzaktan eğitimde ders memnuniyetini, akademik performansı ve öğrenme sürecini etkilediği ifade edilmektedir (Ucar ve Kumtepe, 2016; Ucar ve Kumtepe, 2019; Ucar ve Kumtepe, 2020; Ucar vd., 2020). Bu noktada, motivasyonu sağlayabilmek için kullanıcı dostu platformların tercih edilmesi, ders oryantasyonlarının yapılması ve öğrencilere destekler sunulması gibi uygulamalar önerilmektedir (Wang, Shannon ve Ross, 2013). Araştırma bağlamında ortaya çıkan tema ve ilgili alanyazın uzaktan eğitim sürecinde motivasyonun bir gerek koşul olduğunu göstermekte (Ng, 2019), bu durum ise uzaktan eğitim uygulamalarında öğretim tasarımı ile birlikte motivasyonel tasarımın işe koşulması gerekliliğine işaret etmektedir (Kılınç, 2021).

"Topluluk Hissi" kategorisinde, öğrencilerin uzaktan eğitimde kendilerini yabancı hissettikleri ve yeni öğrenme ortamına alışamadıkları yönünde olumsuz metaforlar yer almaktadır. Araştırma katılımcılarından K35, "Uzaktan eğitim hiç doğayı görmemiş birini ormana terk etmek gibidir. Çünkü ormanda her şeyi tanırsın ama orada barınmazsın.” ifadesi ile uzaktan eğitim ortamına yabancı olduğu düşüncesini yansıtmaktadır. Topluluk hissi, üyelerin bir gruba aidiyet ve üyelerin birbirleri için önemli olduğu duygusu ile üyelerin birbirlerinin ihtiyaçlarını karşılayabileceklerine yönelik inancını ifade etmektedir (McMillan ve Chavis, 1986). Topluluk hissi yüksek olan öğrencilerin algılanan bilişsel öğrenme düzeylerinin daha yüksek olduğu belirtilmektedir (Rovai, 2002). Y1ldız'a (2020) göre, topluluk hissine etki eden faktörler; öğretim elemanı, öğrenci özellikleri, öğretim tasarımı, öğretim yöntemi, etkileşim, iş birliği ve oryantasyondur. Bu bağlamda öğretim elemanlarının uzaktan eğitimde kullanılacak ortamla ilgili bilgilendirilmesi, etkileşime yönelik ortamların tasarlanması, öğrencilere yönelik beklentilerin açık ve net bir şekilde ifade edilmesi ve eğitim sürecinde öğrencilere geri bildirimlerin sağlanması önemli görülmektedir. Ayrıca etkileşimi destekleyen kullanıcı dostu ortamların tercih edilmesi ve bu ortamların kullanımı konusunda öğrencilere rehberlik edilmesi önerilmektedir.

Çalışmaya katılan bazı öğrenciler de uzaktan eğitimin öğrenciye daha fazla sorumluluk yüklediğini düşünmektedirler. $\mathrm{Bu}$ anlamda, "öğrenme sorumluluğu" kategorisinde sunulan, "kendi hayatını yönetemeyen kişi”", "çocuğa verilen sorumluluk" ve "meteor yağmuru" metaforlarını üretmişlerdir. McMahon ve Oliver (2001), uzaktan eğitimde öğrencinin materyale nerede, ne zaman ve ne kadar süreyle erişec ĕgine öğrencinin karar verdiği, başka bir ifadeyle öğrenme sorumluluğunun büyük ölçüde öğrenciye ait olduğunu ifade etmektedirler. Bu bağlamda bir öğrencinin öğrenme kazanımlarına ulaşmak için sistematik olarak planlanmış süreçleri yönetme çabası olarak tanımlananan (Zimmerman ve Schunk, 2011) öz-düzenlemeli öğrenme kavramı önemli bir faktör olarak karşımıza çıkmaktadır.

\subsection{4. Ölçme ve Değgerlendirme Teması}

$\mathrm{Bu}$ araştırma kapsamında incelenen metaforlarda uzaktan eğitimde ölçme değerlendirme süreciyle ilgili 2 farklı olumsuz algı ortaya çıkmaktadır. Bunlardan birincisi, sınav güvenliğinin sağlanamaması; ikincisi ise öğrencinin yönetebileceğinden daha fazla ödev verilmesidir. Sınav güvenliğiyle ilgili "hırsızlık" metaforunu kullanan K1, "Uzaktan eğitim hırsızlık gibidir. Çünkü emek hırsızlığı çok olur. Disiplinli olan özen gösteren emek veren öğrencinin hakkının suistimal edilmesidir. Derslere girmeyen öğrencinin hak yiyerek kopya çekerek çalışan öğrencinin hakkına gasp etmesidir.” gerekçesini 
sunmaktadır. Katılımcı kimliğinin doğrulanamaması ve sınav güvenliğinin sağlanamaması uzaktan eğitimin ölçme değerlendirme boyutunda karşılaştığımız önemli bir sorundur. Uzaktan eğitim süreçlerinde çevrimiçi sınav güvenliğini sağlamaya yönelik sahiplik, bilgi ve katılım faktörlü (Chandra ve Calderon, 2003) kullanıcı kimliğini doğrulamasına yönelik çözümler olsa da bu çözümleri kullanmak için yasal düzenlemelerin yapılması ve etik çerçevesinde birçok konunun dikkate alınması gerekmektedir. Bu soruna karşı1ık; süreç odaklı (Karadağ, 2021) ve geri bildirimlerle desteklenen ödevlerin çözüm olarak sunulduğu görülmektedir (Karadağ, 2014). Alanyazında öğrencilerin ölçme değerlendirme aracı olarak sınavlardan önce ödevleri tercih ettiklerine yönelik bulgular sunulmaktadır (Balta ve Türel, 2013). Haftalık geri bildirimlerle desteklenerek verilen ödevlerin öğrencilerin derse bağl1lığını da artırdığı ifade edilmektedir. Ancak, ödevlerin uzun zaman aldığı durumlarda, öğrenci motivasyonunun düştüğü de belirtilmektedir (Cabi, 2016). Bu bağlamda uzaktan eğitim süreçlerinde her ne kadar öğrenme sorumluluğu öğrencide olsa da öğrencilerin tükenmişlik duygusu yaşamamaları ve motivasyonlarını korumaları için ödev yükünün dengeli olarak planlanması gerekmektedir.

\subsubsection{Acil Uzaktan Öğretim Teması}

Bu tema diğer temalardan farklı olarak pandemiden kaynaklı acil geçiş durumuna yönelik olumsuz metaforları içermektedir. Araştırmaya katılan 2 öğrenci, uzaktan eğitimin tüm eğitim kademelerini etkilediği ve bir mecburiyet haline geldiğini düşünmektedir. Pandemi öncesinde uzaktan eğitim bir seçenek olarak görülürken pandemi şartlarıyla birlikte eğitimin her kademesi için bir zorunluluk haline gelmiştir (Al-Lily, Ismail, Abunasser ve Alqahtani, 2020). Öte yandan, "acil dönüşüm” kategorisinde uzaktan eğitim kavramı, "davetsiz misafir" ve "elektrik kesintisi” metaforlarıla açıklanmaktadır. Bozkurt ve Sharma (2020b) ile Hodges ve diğerleri (2020), eğitim sisteminin pandemi gibi beklenmedik bir küresel krize hazırlıklı olmadığını ifade etmektedir. Dolayısıyla bu durum hem etkili ve verimli bir eğitim süreci sağlamak hem de gelecekte ortaya çıkabilecek olası krizlere daha iyi cevap verebilmek, eğitimin devamlılığını sağlayabilmek için (Ossiannilsson, 2021; Xiao, 2021) bu süreçte eğitimde kalite güvencesini sağlayacak (Hamutoglu, 2021) acil eylem planlarının ve yol haritalarının olması gerektiğini göstermektedir.

\section{SONUÇ VE ÖNERILER}

Araştırmada, Covid-19 pandemisi sürecinde uzaktan eğitim yoluyla ders alan yükseköğretim öğrencilerinin uzaktan eğitime yönelik algıları metaforlar yoluyla incelenmiştir. Bu doğrultuda, 82 üniversite öğrencisinden çevrimiçi bir form aracılığıyla veriler toplanmıştır. Bulgulara göre katılımcılar, 68 olumlu ve 81 olumsuz metafor üretmişlerdir. Olumlu metaforlar "esneklik", "kullanışl1lık", "öğrenci katılımı" ve "uygunluk" temaları; olumsuz metaforlar ise "öğretim süreci”, "öğrenci durumu”, "kullanışlılık", "ölçme değerlendirme" ve "acil uzaktan öğretim” temaları altında gruplandırılmıştır (Şekil 1). 


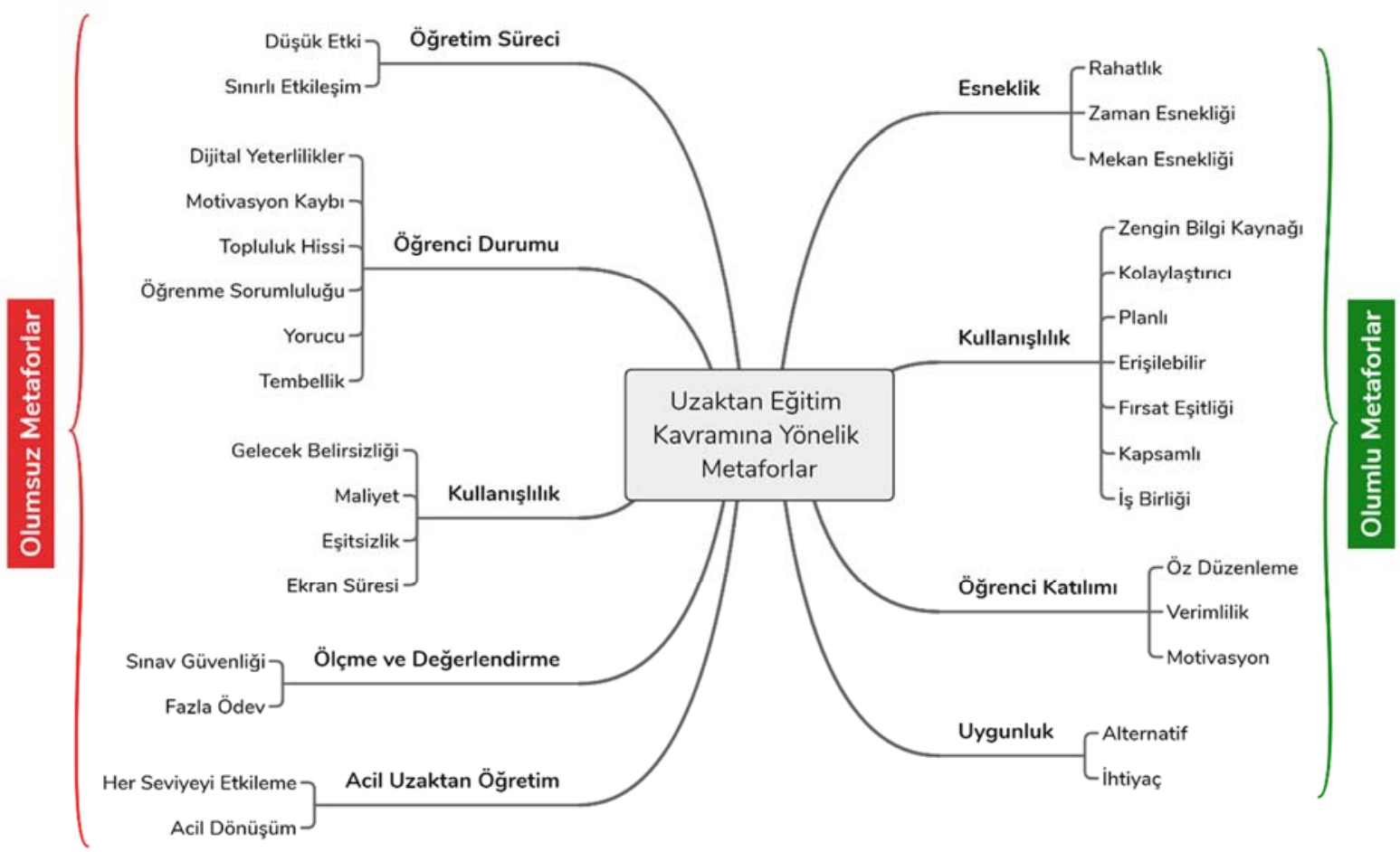

Şekil 1: Uzaktan Eğitim Kavramına Yönelik Olumlu ve Olumsuz Metaforlar

Olumlu metaforlarda en yoğun ifade edilen görüş $(n=41)$; uzaktan eğitimin, öğrencilere rahatlık ve zaman-mekân esnekliği sunduğu yönünde ortaya çıkmıştır (Tablo 3). Bu durum uzaktan eğitimin geleneksel tanımlarında ortaya çıkan zaman ve yer bağlamındaki esnekliği sağladığını gösteren bir bulgudur. "Kullanışlılık" teması bağlamında ise; öğrenciler uzaktan eğitimi, zengin bilgi kaynağı, kolaylaştırıcı, planlı, erişilebilir, fırsat eşitliği, kapsamlı ve iş birliği kategorileriyle değerlendirmektedir. Bu noktada çalışma bulguları uzaktan eğitimin sosyal adalet, eşitlik ve hakkaniyet gibi kritik öneme sahip boşlukları tamamlamada önemli görevler üstlendiğini göstermektedir. Öte yandan öğrencilerde uzaktan eğitimde kendi öğrenme sorumluluklarının daha fazla olduğu şeklinde bir algı da bulunmaktadır. Bu konuda öğrencilerin öz-düzenleme becerilerinin uzaktan eğitimdeki başarıya ve derse motivasyonuna olan etkisinin dikkate alınması gerekliliğine işaret etmektedir. Öğreticiler ve kurumlar, ders dışı etkileşimi ve iletişimi artırarak öğrencilere rehberlik hizmetleri sunulabilir. Son olumlu tema olan "uygunluk" temasına göre; öğrenciler, uzaktan eğitimi yüz yüze eğitime bir alternatif olarak görmekte ve pandemi şartlarından dolayı bir mecburiyet olarak değerlendirmektedir. Bu noktada öğrencilerin yüz yüze ve uzaktan eğitimi karşılaştırma mecburiyetinde hissettikleri görüşü ortaya çıkmaktadır. Dolayısıyla özellikle pandemi sonrası dönemde yapılacak karma/hibrit uygulamaların öğrencilerin daha sağlıklı bir değerlendirme yapmalarına olanak sağlayacağı düşünülmektedir.

Olumsuz metaforlardan "öğretim süreci" temasında "düşük etki" kategorisi $(n=27)$ en fazla öne çıkan kategoridir (Tablo 4). Öğrenciler uzaktan eğitimin etkililiğinin yüz yüze eğitime göre daha az olduğunu düşünmektedirler. $\mathrm{Bu}$ bağlamda kurumların uzaktan eğitimde etkililiğin yetersizliğinin sebeplerine yönelik incelemeler ve düzenlemeler yapmaları gerektiği düşüncesi önemli bir ihtiyaç olarak ortaya çıkmaktadır. Özellikle içeriğin kalitesi ve kalite güvencesi sağlanmasına yönelik bir ihtiyacın bu tema bağlamında ortaya çıkması da ayrıca dikkat çekicidir. Ayrıca öğrenciler, uzaktan eğitimde etkileşimin de yetersiz olduğunu belirtmektedirler. Dolayısıyla uzaktan eğitim yoluyla öğrenme 
içeriğinin sunulmasında etkileşimi artırmaya yönelik öğretim tasarımı yapılmasının önemi bu tema bağlamında ortaya çıkmaktadır. "Öğrenci durumu" temasında; uzaktan eğitim sürecinin internet, bilgisayar veya tablet gibi dijital ihtiyaçlara sebep olduğu, öğrencilerin motivasyon kaybı yaşadıkları, kendilerini yalnız ve gruptan bağımsız hissettikleri görülmüştür. Öte yandan bazı öğrenciler için uzaktan eğitimin yorucu olduğu bazı öğrenciler için de tembelliğe sebep olduğu belirlenmiştir. "Kullanışlılık" temasında, "gelecek belirsizliği", "maliyet", "eşitsizlik" ve "ekran süresi” kategorileri ortaya çıkmıştır. Öğrenciler Covid-19 pandemi sürecinin belirsizliğine bağlı olarak devam etmekte olan uzaktan eğitim süreçlerini de belirsiz olarak görmektedirler. Bu süreçte, özellikle internet kullanımından dolayı uzaktan eğitimin maliyetli olduğu düşünülmektedir. İnternet ihtiyacıyla ilgili olarak pandemi sürecinde Milli Eğitim Bakanlığı ve YÖK hizmet sağlayıcı kurumlarla protokoller imzalayarak öğrencilere uzaktan eğitim sürecinde kullanabilecekleri internet kotası sunarak destek sağlamıştır. Ancak özellikle çevrimiçi videoların sıklıkla kullanıldığı hesaba katıldığında bu yönde kotayı arttıracak düzenlemelere ihtiyaç olduğu düşünülmektedir. Maliyet kategorisiyle bağlantılı olarak uzaktan eğitimin öğrenciler arasındaki eşitsizlikleri ortaya çıkardığı ifade edilmiştir. İnternet altyapısının bulunmadığı yerlerde ikamet eden, maddi imkânlardan dolayı internete veya bilgisayara erişemeyen sosyo-ekonomik durumu zayıf olan öğrenciler dikkate alınarak öğretim süreci tasarımı yapılması fikri öne çıkmaktadır. Yukarıda bahsi geçen temalar eğitime erişimde firsat eşitliği sağlanması kadar ülkemizde yer alan dijital bölünme ve bu bölünmeyle ortaya çıkan bilgi açığı ve bilgi kayıplarını azaltmaya yönelik önleyici mekanizmaların geliştirilmesi gerekliliğine işaret etmektedir. "Ölçme ve Değerlendirme" teması, uzaktan eğitimde sınav güvenliğinin yetersiz olduğu ve öğrencilere fazla ödev verildiği sonuçlarını ortaya koymaktadır. Öğrencilere göre, uzaktan eğitimde yapılan sınavlarda kopya çekilmesi önlenememekte ve çalışan öğrenci ile çalışmayan öğrencinin ayrımı yapılamamaktadır. Ayrıca bazı öğrencilere göre de öğreticiler değerlendirme sürecinde fazla ödevler vermektedir. Bu doğrultuda sonuç odaklı ve kopya çekmenin daha kolay olduğu çoktan seçmeli sınavlar yapmak yerine süreç odaklı değerlendirmeler yaparak e-portfolyo, araştırma ödevleri, çevrimiçi tartışmalar gibi alternatif ölçme değerlendirme araçları kullanılabilir. Ödevlerin zamanı ve ödev teslim süresi, öğrenci yeterlilikleri dikkate alınarak planlanabilir. Olumsuz metafor grubunun sonuncusu olan "acil uzaktan öğretim" temasında uzaktan eğitimin pandemiden kaynaklı olarak her kademedeki öğrencinin hayatına ani bir şekilde girdiği yönünde görüşler yer almaktadır. Bu durum pandemiyle beraber ortaya çıkan ve eğitimin devamlılığını sağlamak için sunulan uygulamaların öğrencileri çok yönlü ve çok boyutlu bir şekilde etkilemesi, pandemi sonrası dünyada hem öğrencilerin hem de eğitim sisteminin kendini sıfırlaması, eğitimde bir reform hareketinin başlaması ve eğitim sisteminin yeterince çalışmayan yönlerinin güçlendirilmesi için bir gereksinim olduğunu göstermektedir. Her ne kadar pandemiyle ortaya çıkan birçok boyutta farklı kayıplar yaşamamıza sebep olsa da pandemi gerçekliğini kabullenip gerçekçi değerlendirmeler yaparak bu krizi bir fırsata çevirebilir; yükseköğretimin güçlü yanlarını pekiştirerek, zayıf yanlarını ise iyileştirerek Türkiye'de yükseköğretim sistemini yeniden şekillendirebiliriz.

Bu çalışma bulguları bağlamında karar vericiler, kurumlar, eğitimciler ve öğrencilere yönelik sunulan öneriler aşağıda yer almaktadır.

Karar vericilere öneriler:

Eğitimin evrensel bir hak olduğu ve her ne koşul olursa olsun eğitimin sürdürülebilirliğini sağlamak gerekliliği düşüncesiyle karar vericilerin acil durumlarda işe koşabilecekleri stratejik planlarının geliştirilmesine ihtiyaç vardır. 
Kurumlara öneriler:

Pandemi deneyim, ile uzaktan eğitim yoluyla sağlanan esnek öğrenme yaklaşımının öğrenciler tarafından benimsendiği görülmektedir. $\mathrm{Bu}$ bağlamda pandemi sonrası yeni normalde kurumların harmanlanmış, hibrit öğrenme modellerine yönelik hazırlık yapması ve ders içeriklerini bu yönde geliştirmeleri önerilmektedir.

Ayrıca pandemi sırasında en çok sorun yaşanan alanlardan birisinin ölçme ve değerlendirme uygulamaları olduğu, mevcut ölçme ve değerlendirme stratejilerin etkili sonuçlar doğurmadığı gibi eşitlik, adalet ve hakkaniyeti sağlamada yetersiz kaldığı görülmüştür. Bu noktada özellikle çevrimiçi sınav güvenliğini sağlamaya yönelik tedbirlerin yanı sıra süreç odaklı ölçme ve değerlendirme yaklaşımlarının ders müfredatlarına daha fazla ilişkilendirilmesinin etkili sonuçlar yaratacă̆ı düşünülmektedir.

Eğitimcilere öneriler:

Hem olumsuz metaforlar hem de olumlu metaforlar bağlamında öğrenme motivasyonunun, öğrencilerin uzaktan eğitim sürecine katılım, akademik performans, etkili ve verimli öğrenme süreçlerinin yaşanmasında kritik öneme sahip bir faktör olduğu görülmektedir. Bu noktadan hareketle öğretim tasarımı süreçlerinde motivasyon tasarımı süreçlerinin de ilişkilendirilmesinin uzaktan eğitim süreçlerini olumlu yönde etkileyeceği düşünülmekte; motivasyon tasarımı ile uzaktan eğitim süreçlerinin iyileştirilmesi önerilmektedir.

Öğrencilere öneriler:

Öz-düzenleme, öz-yönelim, öz-yeterlilik gibi becerilere sahip öğrencilerin uzaktan eğitim süreçlerini daha etkili yürütebildikleri; öğrenme sorumluluğunu daha fazla üstlenen öğrencilerin daha anlamlı öğrenme deneyimleri yaşadıkları görülmektedir. Bu bağlamda öğrencilerin iş birliğine açık bir şekilde uzaktan eğitim süreçlerine katılmaları ve kendi öğrenme hedeflerini belirleyerek öğrenme sorumluluklarını daha fazla almaları önerilmektedir. 


\section{KAYNAKLAR}

Ağır, F. (2007). Özel okullarda ve devlet okullarında çalışan ilköğretim öğretmenlerinin uzaktan eğitime karşl tutumlarının belirlenmesi (Yüksek lisans tezi). Balıkesir Üniversitesi, Fen Bilimleri Enstitüsü, Balıkesir.

Ala-Mutka, K. (2011). Mapping digital competence: Towards a conceptual understanding. European Union. Erişim adresi: http://www.dctest.org/uploads/6/8/7/0/68701431/jrc67075_tn.pdf.

Al-Lily, A. E., Ismail, A. F., Abunasser, F. M., \& Alqahtani, R. H. A. (2020). Distance education as a response to pandemics: Coronavirus and Arab culture. Technology in Society, 63, 101317. https://doi.org/10.1016/j.techsoc.2020.101317

Altinpulluk, H. (2021). Determination of Preschool Teacher Candidates' Views on the Learning Management System Used in the COVID-19 Pandemic Process. In Bozkurt, A. (Eds.), Handbook of Research on Emerging Pedagogies for the Future of Education: Trauma-Informed, Care, and Pandemic Pedagogy (pp. 209-229). IGI Global. Erişim adresi: http://doi:10.4018/978-1-7998-7275-7.ch011.

Alvarez, A. J. (2020). The phenomenon of learning at a distance through emergency remote teaching amidst the pandemic crisis. Asian Journal of Distance Education, 15(1), 144-153. Erişim adresi: http://www.asianjde.org/ojs/index.php/AsianJDE/article/view/453

Anderson, J. (2020). Brave New World The coronavirus pandemic is reshaping education. https://qz.com/1826369/how-coronavirus-is-changing-education/, web adresinden 24 Şubat 2021'de edinilmiştir.

Anderson, T. (2003). Getting the mix right again: An updated and theoretical rationale for interaction. The International Review of Research in Open and Distributed Learning, 4(2). Erişim adresi: https://doi.org/10.19173/irrodl.v4i2.149

Aristovnik, A., Keržič, D., Ravšelj, D., Tomaževič, N., \& Umek, L. (2020). Impacts of the COVID-19 pandemic on life of higher education students: A global perspective. Sustainability, 12(20), 8438. Erişim adresi: https://doi.org/10.3390/su12208438

Arkorful, V., \& Abaidoo, N. (2015). The role of e-learning, advantages and disadvantages of its adoption in higher education. International Journal of Instructional Technology and Distance Learning, 12(1), 29-42. Erişim adresi: https://www.ijern.com/journal/2014/December-2014/34.pdf

Ateş, A., ve Altun, E. (2008). Bilgisayar öğretmeni adaylarının uzaktan eğitime yönelik tutumlarının çeşitli değiş̧enler açısından incelenmesi. Gazi Eğitim Fakültesi Dergisi, 28(3), 125-145. Erişim adresi: https://doi.org/10.17152/GEFD.42014

Bağrıç̧ı Yılmaz, A. (2019). Distance and face-to-face students' perceptions towards distance education: A comparative metaphorical study. Turkish Online Journal of Distance Education, 20(1), 191-207. Erişim adresi: https://doi.org/10.17718/tojde.522705

Balta, Y., ve Türel, Y. K. (2013). Çevrimiçi uzaktan eğitimde kullanılan farklı ölçme değerlendirme yaklaşımlarına ilişkin bir inceleme. Turkish Studies, 8(3), 37-45. Erişim adresi: http://dx.doi.org/10.7827/TurkishStudies.4271

Barış, M. F. (2015). Üniversite öğrencilerinin uzaktan öğretime yönelik tutumlarının incelenmesi: Namık Kemal Üniversitesi örneği. Sakarya University Journal of Education, 5(2), 36-46. https://doi.org/10.19126/suje.38758

Başar, M., Arslan, S., Günsel, E., \& Akpınar, M. (2019). Öğretmen Adaylarının Uzaktan Eğitim Algısı. Journal of Multidisciplinary Studies in Education, 3(2), 14-22. Erişim adresi: https://dergipark.org.tr/en/pub/jmse/issue/45032/555407.

Biriş̧̧i, S. (2013). Video konferans tabanlı uzaktan eğitime ilişkin öğrenci tutumları ve görüşleri. Journal of Instructional Technologies \& Teacher Education, 2(1). 24-40. Erişim adresi: https://dergipark.org.tr/en/pub/jitte/issue/25080/264691

Bond, M. (2020). Schools and emergency remote education during the COVID-19 pandemic: A living rapid systematic review. Asian Journal of Distance Education, 15(2), 191- 247. Erişism adresi: http://www.asianjde.org/ojs/index.php/AsianJDE/article/view/517

Boz, A. (2019). Öğretmen adaylarının teknoloji kabullenme ve kullanımı bağlamında uzaktan eğitim algılarının incelenmesi (Yüksek lisans tezi). Necmettin Erbakan Üniversitesi, Eğitim Bilimleri Enstitüsü, Konya. 
Bozkurt, A. (2020). Koronavirüs (Covid-19) pandemisi sırasında ilköğretim öğrencilerinin uzaktan eğitime yönelik imge ve algıları: Bir metafor analizi. Uşak Üniversitesi Eğitim Araştırmaları Dergisi, 6(2), 1-23. https://doi.org/10.29065/usakead.777652

Bozkurt, A., \& Sharma, R. C. (2020a). Education in normal, new normal, and next normal: Observations from the past, insights from the present and projections for the future. Asian Journal of Distance Education, 15(2), ix. https://doi.org/10.5281/zenodo.4362664

Bozkurt, A., \& Sharma, R. C. (2020b). Emergency remote teaching in a time of global crisis due to CoronaVirus pandemic. Asian Journal of Distance Education, 15(1), i-vi. https://doi.org/10.5281/zenodo.3778083

Bozkurt, A., Jung, I., Xiao, J., Vladimirschi, V., Schuwer, R., Egorov, G., .. \& Paskevicius, M. (2020). A global outlook to the interruption of education due to COVID-19 pandemic: Navigating in a time of uncertainty and crisis. Asian Journal of Distance Education, 15(1), 1-126. https://doi.org/10.5281/zenodo.3878572

Büyüköztürk, Ş. (2010). Bilimsel Araştırma Yöntemleri. Ankara: PEGEM Yayınları.

Chandra, A., \& Calderon, T. G. (2003). Toward a biometric security layer in accounting systems. Journal of Information Systems, 17(2), 51-70. https://doi.org/10.2308/jis.2003.17.2.51

Cortazzi, M., \& Jin, L. (1999). Bridges to learning metaphors of teaching, learning and language. In L. Cameron and G. Low (Eds.), Researching and applying metaphor (pp. 149-160). United Kingdom: Cambridge University Press. https://doi.org/10.1017/cbo9781139524704.011

Creswell, J. W. (2013). Qualitative inquiry and research design: Choosing among five approaches. Sage Publications, Thousand Oaks.

Çivril, H., Aruğaslan, E., \& Özkara, B. Ö. (2018). Uzaktan eğitim öğrencilerinin uzaktan eğitime yönelik algıları: bir metafor analizi. Ĕ̈itim Teknolojisi Kuram ve Uygulama, 8(1), 39-59. https://doi.org/10.17943/etku.310168

Durak, G., Çankaya, S. ve İzmirli, S. (2020). COVID-19 Pandemi Döneminde Türkiye’deki Üniversitelerin Uzaktan Eğitim Sistemlerinin İncelenmesi. Necatibey Eğitim Fakültesi Elektronik Fen ve Matematik Eğitimi Dergisi, 14(1), 787-809. https://doi.org/10.17522/balikesirnef.743080

Ertuğ, C. (2020). Coronavirüs (Covid-19) pandemisi ve pedagojik yansımaları: Türkiye'de açık ve uzaktan eğitim uygulamaları. Açıöğretim Uygulamaları ve Araştırmaları Dergisi, 6(2), 11-53. Erişim adresi: https://dergipark.org.tr/en/pub/auad/issue/55662/761354

Fidan, M. (2016). Uzaktan eğitim öğrencilerinin uzaktan eğitime yönelik tutumları ve epistemolojik inançları. Hacettepe Üniversitesi Eğitim Fakültesi Dergisi, 31(3),536-550. https://doi.org/10.16986/huje.2016016666

Fidan, M. (2017). Metaphors of blended learning'students regarding the concept of distance education. International Online Journal of Educational Sciences, 9(1). https://doi.org/10.15345/iojes.2017.01.017

Forceville, C. (2002). The identification of target and source in pictorial metaphors. Journal of Pragmatics, 34, 1 14. https://doi.org/10.1016/s0378-2166(01)00007-8

Galusha, J. M. (1998). Barriers to learning in distance education. http://jscarcella.academic.csusb.edu/EText_Shea/She504/Assignments/WR3_DL_barriers.htm, web adresinden 24 Şubat 2021'de edinilmiştir.

Garrison, D. R., \& Cleveland-Innes, M. (2005). Facilitating cognitive presence in online learning: Interaction is not enough. The American journal of distance education, 19(3), 133-148. https://doi.org/10.1207/s15389286ajde1903_2

Gök, B. (2011). Uzaktan ĕgitimde görev alan öğretim elemanlarının uzaktan ĕğitim algısı (Yüksek lisans tezi). Gazi Üniversitesi, Bilişim Enstitüsü, Ankara.

Greenberg, G. (1998). Distance education technologies: Best practices for K-12 settings. IEEE Technology and Society Magazine, 17(4). https://doi.org/10.1109/44.735862

Gündüz, A. Y. (2013). Öğretmen adaylarının uzaktan eğitim algısı (Yüksek lisans tezi). Sakarya Üniversitesi, Eğitim Bilimleri Enstitüsü, Sakarya.

Güneş, A., ve Fırat, M. (2016). Açık ve uzaktan öğrenmede metafor analizi araştırmaları. Açıköğretim Uygulamaları ve Araştırmalart Dergisi, 2(3), 115-129. Erişim adresi: https://dergipark.org.tr/en/pub/auad/issue/34059/377003 
Gürer, M. D., Tekinarslan, E. ve Yavuzalp, N. (2016). Çevrimiçi Ders Veren Öğretim Elemanlarının Uzaktan Eğitim Hakkındaki Görüşleri. Turkish Online Journal of Qualitative Inquiry, 7(1). https://doi.org/10.17569/tojqi.74876

Hamutoglu, N. B. (2021). A Road Map for the COVID-19 Pandemic Process to Ensure Quality of Assurance Active Learning Strategies in Online Learning Environments: How to Plan, Implement, Evaluate, and Improve Learning Activities. In Bozkurt, A. (Eds.), Handbook of Research on Emerging Pedagogies for the Future of Education: Trauma-Informed, Care, and Pandemic Pedagogy (pp. 101-126). IGI Global. http://doi:10.4018/978-1-7998-7275-7.ch006

Hannay, M., \& Newvine, T. (2006). Perceptions of distance learning: A comparison of online and traditional learning. Journal of Online Learning and Teaching, 2(1), 1-11. Erişim adresi: https://jolt.merlot.org/documents/MS05011.pdf

Hardy, D. W., \& Boaz, M. H. (1997). Learner development: Beyond the technology. New Directions for Teaching and Learning, 71, 41-48.

Hirumi, A. (2002). The design and sequencing of e-learning interactions: A grounded approach. International Journal on E-Learning, 1(1), 19-2. Erişim adresi: https://www.learntechlib.org/primary/p/8390/

Hobson, T. D., \& Puruhito, K. K. (2018). Going the Distance: Online Course Performance and Motivation of Distance Learning Students. Online Learning, 22(4), 129-140. http://dx.doi.org/10.24059/olj.v22i4.1516

Hodges, C., Moore, S., Lockee, B., Trust, T., \& Bond, A. (2020, March 27). The difference between emergency remote teaching and online learning. EDUCAUSE Review. https://er.educause.edu/articles/2020/3/thedifference-between-emergency-remote-teaching-and-online-learning

Horzum, B. (2003). Öğretim elemanlarının internet destekli eğitime yönelik düşünceleri (Sakarya üniversitesi örneği) (Yüksek lisans tezi). Sakarya Üniversitesi Sosyal Bilimler Enstitüsü, Sakarya.

Horzum, M. B., Albayrak, E. ve Ayvaz, A. (2012). Sınıf öğretmenlerinin hizmet içi eğitimde uzaktan eğitime yönelik inançları. Ege Eğitim Dergisi, 13(1), 55-72. Erişim adresi: https://dergipark.org.tr/en/pub/egeefd/issue/4904/67214

Howell, J. (2012). Teaching with ICT: Digital pedagogies for collaboration and creativity. Melbourne: Oxford University Press.

Howland, J. L., \& Moore, J. L. (2002). Student perceptions as distance learners in Internet-based courses. Distance education, 23(2), 183-195. https://doi.org/10.1080/0158791022000009196

Jung, I., \& Rha, I. (2000). Effectiveness and cost-effectiveness of online education: A review of the literature. Educational Technology, 40(4), 57-60. https://doi.org/10.4324/9780203803738.ch33

Karadağ, N. (2014). Açık ve uzaktan eğitimde ölçme ve değerlendirme: Mega üniversitelerdeki uygulamalar (Doktora tezi). Anadolu Üniversitesi, Sosyal Bilimleri Enstitüsü, Eskişehir.

Karadağ, N. (2021). Açıköğretim Sistemi’nde çevrimiçi sınav uygulamasının sınav hazırlama sürecine etkisi. Açıöğretim Uygulamaları ve Araştırmaları Dergisi, 7(1), 45-60. Erişim adresi: https://dergipark.org.tr/en/pub/auad/issue/60075/857187

Kayaduman, H., \& Battal, A. (2021). The University Instructors' Opinions About Emergency Remote Education in Turkey. In Bozkurt, A. (Ed.), Handbook of Research on Emerging Pedagogies for the Future of Education: Trauma-Informed, Care, and Pandemic Pedagogy (pp. 66-81). IGI Global. http://doi:10.4018/978-1-7998-7275-7.ch004

Keegan, D. (1988). Problems in defining the field of distance education. The American Journal of Distance Education, 2(2), 4-11. https://doi.org/10.1080/08923648809526619

Kılınç, H. (2021). Opinions of Field Experts on Practices That Will Increase the Motivation Levels of Learners During the COVID-19 Pandemic Process. In Bozkurt, A. (Eds.), Handbook of Research on Emerging Pedagogies for the Future of Education: Trauma-Informed, Care, and Pandemic Pedagogy (pp. 191-208). IGI Global. http://doi:10.4018/978-1-7998-7275-7.ch010

Kırali, F. N., \& Alcı, B. (2016). Üniversite öğrencilerinin uzaktan eğitim algısına ilişkin görüşleri. İstanbul Aydın Üniversitesi Dergisi, 8(30), 55-83. Erişim adresi: https://dergipark.org.tr/tr/pub/iaud/issue/30078/324645

Lakoff, G., \& Johnson, M. (2003). Metaphors we live by. University of Chicago Press 
Lawler, P. A. (2003). Teachers as adult learners: A new perspective. New Directions for Adult and Continuing Education, 2003(98), 15-22. https://doi.org/10.1002/ace.95

McMahon, M., \& Oliver, R. (2001). Promoting self-regulated learning in an online environment. In proceedings of Ed-Media 2001 World Conference on Educational Multimedia, Hypermedia \& Telecommunications (pp. 1299-1305). Charlottesville, VA: Association for the Advancement of Computing in Education (AACE).

McMillan, D. W., \& Chavis, D. M. (1986). Sense of community: A definition and theory. Journal of Community Psychology, 14(1), 6-23. https://doi.org/10.1002/1520-6629(198601)14:1\%3C6::aidjcop2290140103\%3E3.0.co;2-i

Midkiff, S. F., \& DaSilva, L. A. (2000). Leveraging the web for synchronous versus asynchronous distance learning. International Conference on Engineering Education, 2000, 14-18.

Moore, G. M. (2012). Handbook of distance education. New York: Routledge.

Moore, M. G. (1989). Three types of interaction. American Journal of Distance Education, 3(2), 1-7. https://doi.org/10.1080/08923648909526659

Moore, M. G., \& Kearsley, G. (2012). Distance education: A systems view of online learning (3rd ed.). Belmont, CA: Wadsworth.

Naidu, S. (2016). Mainstreaming open, flexible, and distance learning. In Kwok-Wing Lai, Sarah Stein, Penny Field, and Keryn Pratt (Eds.), Our World in Your Place: 30 years of distance learning and teaching at the University of Otago(pp. 92-108). University of Otago. Erişim adresi: http://www.thtagj.com/courses/distance_study/otago629551.pdf\#page=102

$\mathrm{Ng}, \mathrm{C}$. (2019). Shifting the focus from motivated learners to motivating distributed environments: a review of 40 years of published motivation research in Distance Education. Distance Education, 40(4), 469-496. https://doi.org/10.1080/01587919.2019.1681892

Ossiannilsson, E. S. (2021). Resilient Sustainable Education for the Future of Education: Emerging Challenges. In Bozkurt, A. (Eds.), Handbook of Research on Emerging Pedagogies for the Future of Education: TraumaInformed, Care, and Pandemic Pedagogy (pp. 16-43). IGI Global. http://doi:10.4018/978-1-7998-72757.ch002

Öz Ceviz, N., Tektaş, N., Basmacı G., \& Tektaş M. (2020). Covid-19 pandemi sürecinde üniversite öğrencilerinin uzaktan eğitime bakışı: Türkiye örneği. Ulakbilge, 52, 1322-1335.

Peters, M. A., Rizvi, F., McCulloch, G., Gibbs, P., Gorur, R., Hong, M., Hwang, Y., Zipin, L., Brennan, M., Robertson, S., Quay, J., Malbon, J., Taglietti, D., Barnett, R., Chengbing, W., McLaren, P., Apple, R., Papastephanou, M., Burbules, N., ... Misiaszek, L. (2020). Reimagining the new pedagogical possibilities for universities post-Covid-19. Educational Philosophy and Theory, 1-44. https://doi.org/10.1080/00131857.2020.1777655

Rovai, A. P. (2002). Sense of community, perceived cognitive learning, and persistence in asynchronous learning networks. The Internet and Higher Education 5 (4), 319-332. https://doi.org/10.1016/s10967516(02)00130-6

Russell, T. (2001). The no significant difference phenomenon as reported in 355 research reports, summaries, and papers: A comparative research annotated bibliography on technology for distance education. Raleigh, NC: Office of Instructional Telecommunications, North Carolina State University

Saban, A. (2008). İlköğretim I. Kademe öğretmen ve öğrencilerinin bilgi kavramına ilişkin sahip oldukları zihinsel imgeler. Ilkögretim Online, $7(2), \quad 421-455 . \quad$ Erişim https://dergipark.org.tr/en/pub/ilkonline/issue/8601/107119

Schunk, D. H., Pintrich, P. R., \& Meece, J. L. (2008). Motivation in education (3rd ed.). Pearson Merrill Prentice Hall.

Sezgin, S. (2021). Acil uzaktan eğitim sürecinin analizi: Öne çıkan kavramlar, sorunlar ve çıkarılan dersler. Anadolu Üniversitesi Sosyal Bilimler Dergisi, 21(1), 273-296. https://doi.org/10.18037/ausbd.902616

Sipahi, K. B. (2019). Mesleki açık ögretim lisesi öğrencilerinin uzaktan ĕgitime yönelik algıladıkları engeller ile tutumları arasındaki ilişkinin incelenmesi (Yüksek lisans tezi). Sakarya Üniversitesi, Eğitim Bilimleri Enstitüsü, Sakarya. 
Sklar, J. (2020, April 24). 'Zoom fatigue' is taxing the brain. Here's why that happens. National Geographic. Erişim adresi: https:/www.nationalgeographic.com/science/2020/04/coronavirus-zoom-fatigue-is-taxing-thebrain-here-is-why-that-happens/.

Şahin İzmirli, Ö. ve Mısırlı, Z. A. (2018). Öğretim elemanlarinin uzaktan eğitime ilişkin metaforik algilari. Uluslararasi Necatibey Eğitim ve Sosyal Bilimler Araştırmaları Kongresi (UNESAK 2018). Balıkesir, Türkiye.

Taş, H., Yavuzalp, N. ve Gürer, M. (2016). BÖTE Bölümü öğrencilerinin uzaktan eğitime yönelik algılarının metaforlar yoluyla belirlenmesi. 4th International Instructional Technologies \& Teacher Education Symposium. Elazig, Turkey.

Tuncay, N., \& Özçinar, Z. (2009). Distance education students' "metaphors". Procedia-Social and Behavioral Sciences, 1(1), 2883-2888. https://doi.org/10.1016/j.sbspro.2009.01.513

Ucar, H., \& Kumtepe, A. T. (2016, March). ARCS-V Motivational Design Approach, Interaction, and e3-learning: Rethinking Motivation for Distance Education. In Society for Information Technology \& Teacher Education International Conference (pp. 413-418). Association for the Advancement of Computing in Education (AACE).

Ucar, H., \& Kumtepe, A. T. (2019). Be Motivated and Motivate: An Interview with John M. Keller. eLearn Magazine. https://doi.org/10.1145/3329488.3331178

Ucar, H., \& Kumtepe, A. T. (2020). Effects of the ARCS-V-based motivational strategies on online learners' academic performance, motivation, volition, and course interest. Journal of Computer Assisted Learning, 36(3), 335-349. https://doi.org/10.1111/jcal.12404

Uçar, H., Bozkurt, A., Öztürk, A. ve Kumtepe, A. T. (2020). Uzaktan öğrenenlerin eylem yeterlik düzeylerinin incelenmesi. Anadolu Journal of Educational Sciences International (AJESI), 10(1), 303-323. https://doi.org/10.18039/ajesi.682037

Valentine, D. (2002). Distance learning: Promises, problems, and possibilities. Online journal of distance learning administration, 5(3).

Wang, C. H., Shannon, D. M., \& Ross, M. E. (2013). Students' characteristics, self-regulated learning, technology self-efficacy, and course outcomes in online learning. Distance Education, 34(3), 302-323. https://doi.org/10.1080/01587919.2013.835779

Xiao, J. (2021). From Equality to Equity to Justice: Should Online Education Be the New Normal in Education?. In Bozkurt, A. (Eds.), Handbook of Research on Emerging Pedagogies for the Future of Education: Trauma-Informed, Care, and Pandemic Pedagogy (pp. 1-15). IGI Global. http://doi:10.4018/978-1-79987275-7.ch001

Yenilmez, K., Turğut, M. ve Balbağ, M. Z. (2017). Öğretmen adaylarının uzaktan eğitime yönelik tutumlarının bazı değişkenler açısından incelenmesi. Erzincan Üniversitesi Eğitim Fakültesi Dergisi, 19(2), 91-107. https://doi.org/10.17556/erziefd.305902

Yıldırım, A. ve Şimşek, H. (2013). Sosyal Bilimlerde Nitel Araştırma Yöntemleri. Ankara: Seçkin Yayıncılık.

Yıldırım, S., Yıldırım, G., Çelik, E. ve Karaman, S. (2014). Uzaktan eğitim öğrencilerinin uzaktan eğitime yönelik görüşleri: bir ölçek geliştirme çalışması. Eğitim ve Öğretim Araştırmaları Dergisi, 3(3), 365-370.

Yıldız, E. (2020). Çevrimiçi öğrenme ortamlarında uzaktan eğitim öğrencilerinin topluluk hissine etki eden faktörlerin incelenmesi. Eğitimde Nitel Araştırmalar Dergisi, 8(1), 180-205. https://doi.org/10.14689/issn.2148-2624.1.8c.1s.9m

Yıldız, M. (2015). Uzaktan ĕgitim programlarında ders veren ögretim elemanlarının uzaktan ĕgitime yönelik bilgi, inanç ve uygulamaları arasındaki ilişkiler (Yüksek lisans tezi). Hacettepe Üniversitesi, Ankara.

Yılmaz, G. K. ve Güven, B. (2015). Öğretmen adaylarının uzaktan eğitime yönelik algılarının metaforlar yoluyla belirlenmesi. Turkish Journal of Computer and Mathematics Education, 6(2), $299-322$. https://doi.org/10.16949/turcomat.75936

Zimmerman, B. J., \& Schunk, D. H. (2011). Self-regulated learning and performance: An introduction and an overview. In B. J. Zimmerman \& D. H. Schunk (Eds.), Handbook of self-regulation of learning and performance (pp. 1-12). New York, NY: Routledge. 


\section{EXTENDED ABSTRACT}

With the Covid-19 pandemic, face-to-face education was suspended in all educational institutions and distance education was urgently put into practice as an emergency solution. Distance education is defined as the mode of education in which the teacher and student continue teaching-learning activities independent of time and place (Keegan, 1988). It is seen as an advantage that distance education can reach more students, reduce educational costs, and provide equity and equality in education. On the other hand, students are supposed to have digital competencies and some abilities such as being autonomous, self-directed and self-regulated. The success of distance education is influenced by many factors such as student motivation and self-regulation skills, perceptions and attitudes towards distance education, teachers' perceptions towards distance education, institutional support, and policies. However, among these factors, it is stated that student perceptions of distance education are critically important for the academic success of the students in distance education processes (Yıldırım, Yıldırım, Çelik, and Karaman, 2014). In the related literature, there are studies that examine the perceptions of students on distance education at different educational levels. Among these studies, there are also studies that collect data from participants through metaphors. Metaphors are used to collect data on participant experiences in situations where qualitative data collection tools such as observation and interview cannot be used. It provides the most personal data by revealing their unique thoughts, especially without guiding the participant (Güneş and Fırat, 2016). In this context, s this study aims to identify the perceptions and experiences of university students about distance education through metaphors.

In this study, the phenomenology research design which is a qualitative approach was adopted to seek answers to research questions. In the study, students' perceptions of the concept of distance education were collected through metaphors. Metaphors are powerful cognitive tools used by people to understand and explain an abstract and confusing concept (Lakoff and Johnson, 2003). An online form was prepared by the researchers to collect data. In the form, they were asked to complete the survey form using a positive and negative metaphor. Within the scope of the research, 159 university students were reached, but 77 responses that did not comply with the instructions specified in the data collection tool were removed, and the data from 82 participants (62 female, 20 male) were analyzed. The data obtained were analyzed with content analysis, and positive and negative metaphors were coded and categorized under relevant themes. According to the findings obtained through content analysis, the participants produced 68 positive and 81 negative metaphors about distance education. Among the positive metaphors, the themes of "flexibility", "usefulness", "student participation" and "suitability"; "teaching process", "usefulness", "students' situation", "assessment and evaluation" and "emergency distance education" themes were identified as negative metaphors. Flexibility is found to be the most prominent theme in positive metaphors. In this context, students pointed out the convenience of distance education and stated that it offers them time and space flexibility. Regarding the theme of usability, "rich information source", "facilitator", "planned", "accessible", "equal opportunity", "comprehensive" and "cooperation" categories; "self-regulation", "efficiency" and "motivation" categories have emerged in the theme of student participation, and "alternative" and "need" categories have emerged in the theme of conformity. Considering the Covid-19 process, students think that distance education is needed in the context of the last theme and see distance education as an alternative to face-to-face education. Among the negative metaphors, the "teaching process" theme came to the fore as a salient one in the "low impact" category. Students consider that distance education is less effective when compared to face-to-face education. Besides, students state that interaction in distance education is also insufficient. In the "student situation" theme, it has been observed that the distance education process causes digital needs regarding tools and infrastructures such as the internet, computers or tablets. On the other hand, it has been 
determined that distance education is exhaustive for some students. In the theme of "usefulness", "future uncertainty", "cost", "inequality" and "screen time" categories emerged. The theme of "assessment and evaluation" reveals that exam security in distance education is insufficient and students are given too much homework. The last one of the negative metaphor group, "emergency remote education", proposes that distance education has entered the lives of students at all levels suddenly due to the pandemic.

Based on the findings of this study, it is recommended that institutions should investigate the reasons for the inadequacy of distance education. In this context, taking student satisfaction into account, providing content quality emerges as an important issue to pay attention to. In the instructional design processes, measures should be taken by considering the interaction dimension. Alternative assessment tools such as e-portfolio, research assignments, online discussions can be used by making processoriented evaluations instead of doing result-oriented multiple-choice exams for assessment and evaluation security. Homework time and assignment deadline can be planned by considering student competencies. 